\title{
WestVirginiaUniversity
}

THE RESEARCH REPOSITORY @ WVU

Graduate Theses, Dissertations, and Problem Reports

2010

\section{West Virginia principals' knowledge and application of school law}

Nancy Ross Williams

West Virginia University

Follow this and additional works at: https://researchrepository.wvu.edu/etd

\section{Recommended Citation}

Williams, Nancy Ross, "West Virginia principals' knowledge and application of school law" (2010).

Graduate Theses, Dissertations, and Problem Reports. 2962.

https://researchrepository.wvu.edu/etd/2962

This Dissertation is protected by copyright and/or related rights. It has been brought to you by the The Research Repository @ WVU with permission from the rights-holder(s). You are free to use this Dissertation in any way that is permitted by the copyright and related rights legislation that applies to your use. For other uses you must obtain permission from the rights-holder(s) directly, unless additional rights are indicated by a Creative Commons license in the record and/ or on the work itself. This Dissertation has been accepted for inclusion in WVU Graduate Theses, Dissertations, and Problem Reports collection by an authorized administrator of The Research Repository @ WVU.

For more information, please contact researchrepository@mail.wvu.edu. 
West Virginia Principals’ Knowledge and Application of School Law

\author{
Nancy Ross Williams
}

Dissertation submitted to the College of Human Resources and Education at West Virginia University in partial fulfillment of the requirements for the degree of

Doctor of Education

in

Educational Leadership Studies

Approved by

Paul E. Chapman, Ph.D., Chair

Sebastián R. Díaz, Ph.D., J.D.

Ernest R. Goeres, Ph.D.

Deborah J. Hendricks, Ed.D.

Ted S. Price, Ph.D.

Mary Ellen Zeppuhar, Ed.D.

Department of Education Leadership Studies

Morgantown, West Virginia

2010

Keywords: Principals, Public School, School Law, West Virginia,

Principal Preparation, Special Education Law

Copyright 2010 Nancy Ross Williams 


\begin{abstract}
West Virginia Principals’ Knowledge and Application of School Law

Nancy Ross Williams
\end{abstract}

Public school principals must be prepared to apply knowledge of school law in a variety of situations. An electronic survey examined West Virginia principals' knowledge and application of school law in five areas: separation of church-state, faculty issues, special education, student issues and tort liability. The study extended previous school law survey research of Brabrand (2003), Littleton, Hiram and Styron (2001), Power (2007) and Schlosser (2006), and utilized adapted or actual survey items from those studies with additional items constructed by the researcher. The purpose of the study was to determine if a relationship existed among West Virginia principals' ability to accurately answer school law questions, given application scenarios and fact-based statements, compared with seven selected independent variables: programmatic level of the school; experience as a teacher; experience as an administrator; type of credentialing program; type of school law course taken; number of school law courses taken; and reported pedagogical construct of course delivery. Open-ended questions allowed principals to list likes/dislikes of university level school law coursework, recommendations for university preparation, recommendations for professional development, and areas of school law not included in the survey. A quantitative causal comparative research design utilized nonparametric measures to analyze quantitative data. Qualitative data was categorized and reported. The study identified six statistically significant differences. Principals' recommendations for university credentialing programs and professional development indicated a compelling need to include coursework and ongoing professional development in knowledge and application of special education law. 


\section{Acknowledgements}

As I take the last step in my dissertation journey, it is with heartfelt gratitude I acknowledge the excellence of the truly engaged learning practices provided in the West Virginia University Educational Leadership Program. Dr. D.J. Hendricks and Dr. Beth Loy gently guided me through the difficult maze of statistics. I am deeply indebted to Dr. Hendricks for her assistance with the statistical analysis for this study. Dr. Mary Ellen Zeppuhar provided the impetus for me to rethink my research emphasis to include special education, a prompt that had important results. Dr. Elizabeth Jones, a pioneer in curriculum reform and assessment, crafted courses and assignments resulting in challenging problem-based learning. Dr. Richard Hartnett guided erudite discussion of issues faced by school leaders. I am grateful to my fellow EDLS Cohort Two members and want to acknowledge the importance of our time together. I learned a great deal from all of you.

My dissertation chair, Dr. Paul Chapman, provided a level of guidance and support that I would wish for every doctoral student. Without his patience, availability, and cogent suggestions, my journey would not have come to an end. To my other committee members, Dr. Diaz, Dr. Goeres, and Dr. Price - many thanks for reading the dissertation and for your salient and sage comments. The unsung hero award goes to Dr. Dick Walls for his serendipitous participation in my oral defense. His expert and eagle eyes opened mine to some overlooked and important details in refining the final manuscript. My webmaster, Chris Chilcoat, provided invaluable technical and design expertise. 
Dr. Randall K. Harley, Professor of Special Education, Emeritus, of the Peabody College of Vanderbilt University, encouraged me to begin a doctoral journey and had a profound influence on my scholarship.

I am also indebted to the expert review panel for their time and expertise. In particular, Howard E. Seufer, Jr, an attorney specializing in school law with the law firm Bowles Rice McDavid Graff and Love, scrutinized items and made suggestions that resulted in greater accuracy and clarity. Other expert panel members provided comments and suggestions that improved the survey. Many thanks to John E. Taylor, professor of law at West Virginia University; Karen B. Larry, EdD, Executive Assistant to the State Superintendent, West Virginia Department of Education (retired); and Linda DePriest, $\mathrm{PhD}$, now Assistant Superintendent for Instructional Support, Metropolitan Nashville City Schools and adjunct professor at Vanderbilt University, for their input and expertise. And while I attempted to be faithful to the reviewers' input and suggestions, as the author, I bear sole responsibility for any errors of fact or interpretation.

On a daily basis, I continue to learn from two school leaders who always keep their focus on what is best for children. I am grateful for the leadership of Patricia Taylor, Superintendent, and Lynette Johnson, Director of Special Instructional Services, of Frederick County Virginia Public Schools, a professional learning community where children are always "the reason” and excellence is expected. It is a privilege to work with both of you for the children of Frederick County. 


\section{Dedication}

This study is dedicated, in part, to the learning and success of public school children in West Virginia. When West Virginia principals are able, through improved preparation and professional development, to make more informed decisions in a more efficient and thorough manner, more of their time can be dedicated to the overarching goal of student learning. The importance of this study will ultimately depend on the application of the knowledge gained from the research findings and implementation of the principals’ own recommendations for professional preparation and professional development.

This study is also dedicated to my family. The love and support of my husband, Gene, and our sons, Ross, James and Ben, is beyond measure. Thank you. My dedication extends to my parents, Dr. Harriet Herron Ross (1926 - 2002) and Dr. Thomas Edgar Ross (1921 - 2005) who highly valued education, who were proud of my work in educating children and who encouraged me in all my endeavors. Spem successus alit. 


\section{Table of Contents}

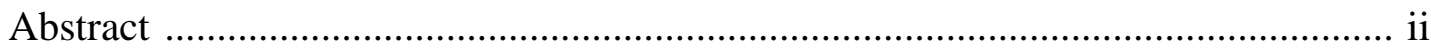

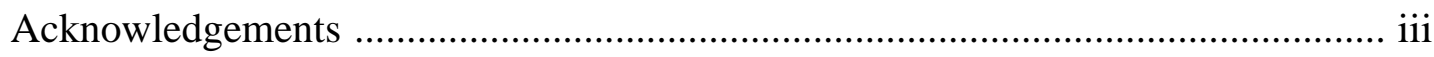

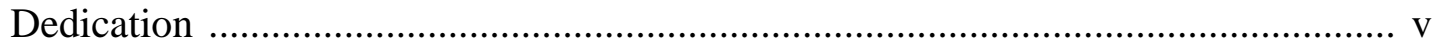

Table of Contents ...................................................................................... vi

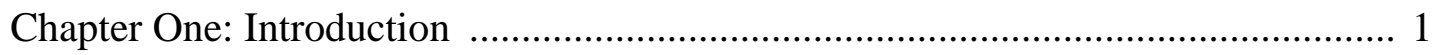

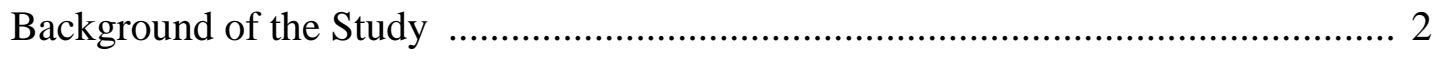

Statement of the Problem ..................................................................................... 2

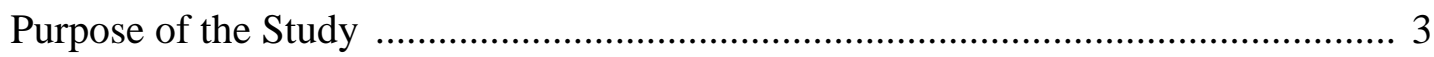

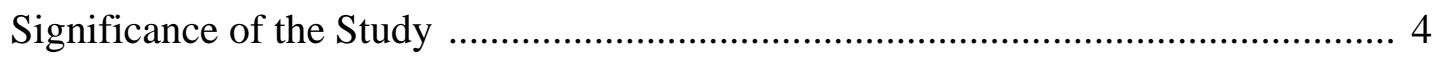

Research Questions and Hypotheses ........................................................... 5

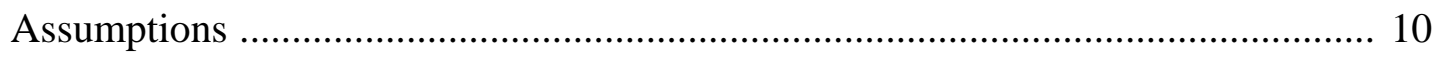

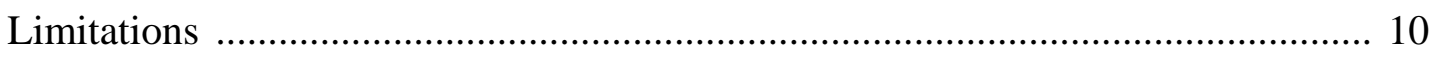

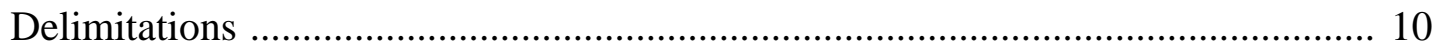

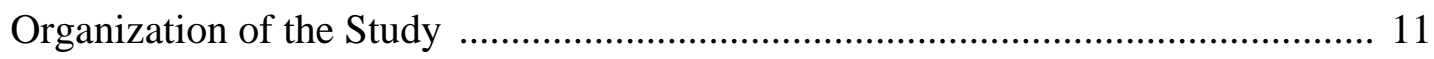

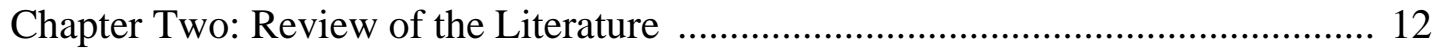

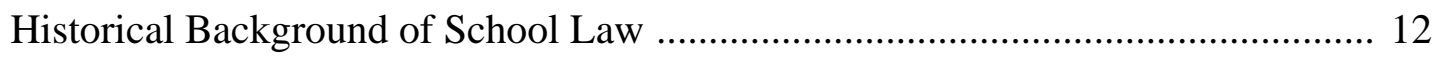

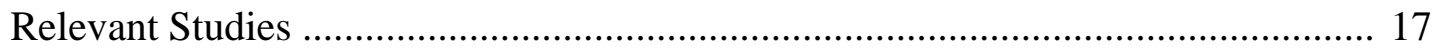

Prior Studies of Principals’ Knowledge of School Law ..................................... 17

Prior Studies of Principals’ Knowledge of Special Education Law ....................... 22

National Focus on Principal Preparation Programs ............................................. 24

Evolution of Principal Preparation Programs ................................................... 26

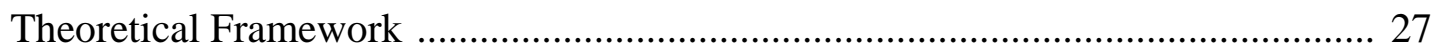


Domains of Principal Leadership ............................................................................ 30

Cognitive Domain .............................................................................. 30

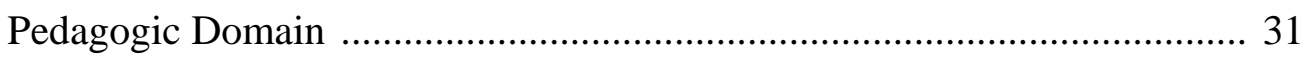

Leadership Domain ................................................................................ 31

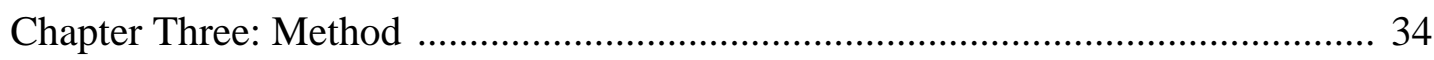

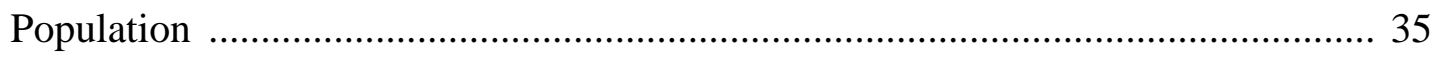

Survey Design ........................................................................................... 35

Procedures for Data Collection ........................................................................ 36

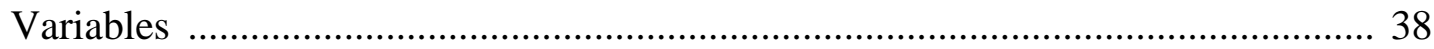

Validity and Reliability ..................................................................................... 39

Chapter Four: Research Findings .......................................................................... 42

Description of Demographics and Study Variables ................................................. 44

Quantitative Research Questions ........................................................................... 47

Research Question One .............................................................................. 47

Research Question Two ....................................................................... 48

Research Question Three ......................................................................... 49

Research Question Four ....................................................................... 51

Research Question Five .................................................................. 52

Research Question Six ............................................................................. 53

Research Question Seven ......................................................................... 54

Perceptions About School Law Preparation and Professional Development .......... 55

Qualitative Questions ..................................................................................... 55

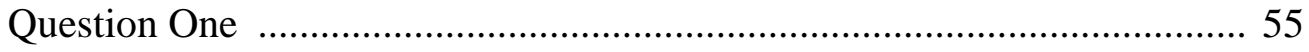




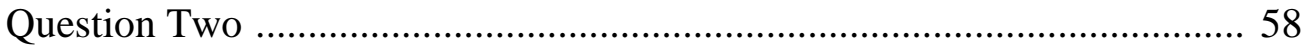

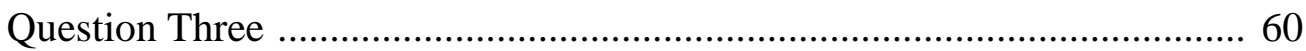

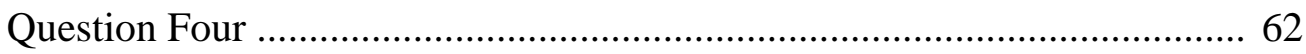

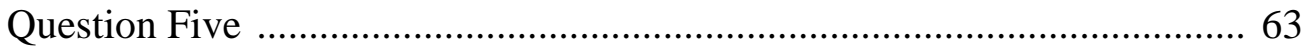

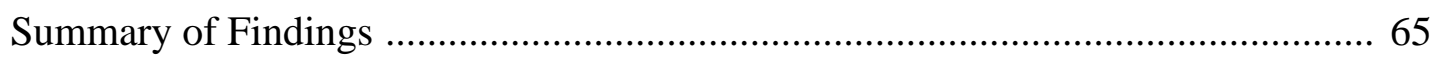

Knowledge Level Findings .................................................................... 66

Application Level Findings ........................................................................... 66

Principal Perceptions About School Law Preparation and Professional

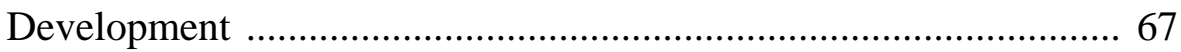

Chapter Five: Summary, Conclusions and Recommendations .................................. 69

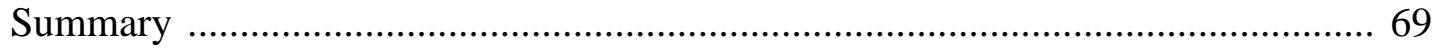

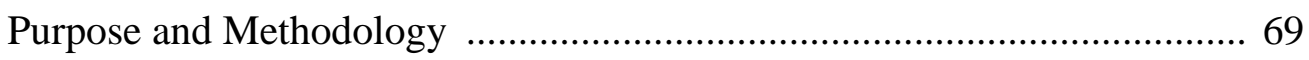

Research Findings ……………………....................................................... 70

Knowledge Level Research Findings …….................................................... 71

Application Level Research Findings .......................................................... 71

Relationship to Theory …………………………….......................................... 71

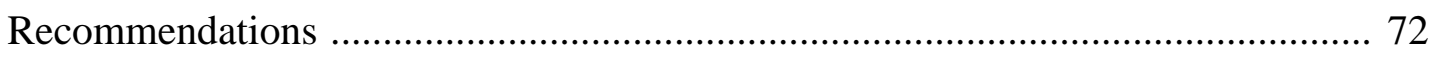

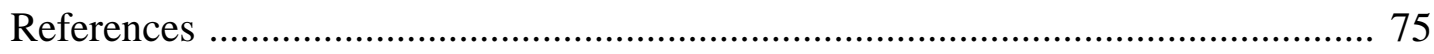

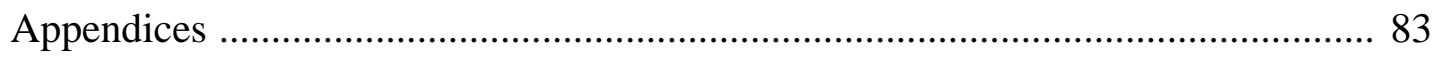

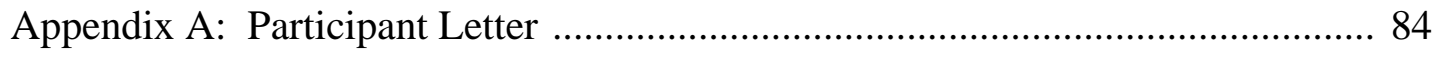

Appendix B: Letter of support from Dr. Paine ……………………………......... 85

Appendix C: IRB Acknowledgement .............................................................. 86

Appendix D: Williams School Law Survey ……………......................................... 87 
Appendix E: Survey Sources and Legal References ......................................... 98

Appendix F: Permission to Use Survey Items - Dr. Brabrand ........................... 108

Appendix G: Permission to Use Survey Items - Dr. Littleton ............................ 109

Appendix H: Permission to Use Survey Items - Dr. Power .............................. 110

Appendix I: Permission to Use Survey Items - Dr. Schlosser ........................... 111

Appendix J: Curriculum Vitae .................................................................. 112 


\section{List of Tables}

Table 1: Questions for Expert Panel for Readability .................................................. 36

Table 2: Frequency Distributions and Descriptive Statistics

of Demographic Factors ………………...................................................... 45

Table 3: Descriptive Statistics for Scores in School Law ......................................... 46 


\section{List of Figures}

Figure 1: The Building Blocks of Educational Leadership

Preparation Programs (adapted)

Figure 2. Principals’ Suggestions for Areas of School Law

Most Beneficial for Professional Development ...................................... 63 


\section{Chapter One}

Public school principals are increasingly faced with challenging legal situations, particularly with regard to separation of church and state, faculty issues, special education, student issues, and tort liability (DeMitchell, 2006; Lane, Connelly, Mead, Gooden, \& Eckes, 2008; Murdkic, Gartin, \& Crabtree, 2007; Yell, 2006; Zirkel, 1997). Often they must respond quickly, appropriately, and efficiently to an unpredictable array of legal issues (Lane et al., 2008). The principal’s timely appropriate response may determine if the issue is resolved. A delay in response or inappropriate response could lead to time-intensive teacher and administrator follow-up and expensive legal costs, resulting in an inefficient and costly impact on the school district, damage to community relations and impaired school/parent relationships (Chambers, Harr, \& Dhanani, 2003; Copenhaver, 2005; Zirkel, 1994).

A brief amici curiae filed in the $9^{\text {th }}$ District Court by the National School Board Association, American Association of School Administrators, and the National Association of Special Education Directors, noted the cost of litigation per case in 19992000 carried an average cost of $\$ 94,600$ (Chambers et al., 2003). The cost of litigation detracts from school districts’ ability to provide high quality educational programs and adds impetus to the importance to understand the impact of variables on principals' knowledge and application of school law.

A case in West Virginia has important implications for educators and school districts. A 1993 jury trial, Doe v. Withers, resulted in fine of $\$ 15,000$ and costs for the action for a regular education high school history teacher in Taylor County who failed to provide accommodations in a student’s individual education plan (Zirkel, 1994). 


\section{Background of the Study}

The Constitution of West Virginia, 1877, Article XII, Section 1, provides the following guide for establishment of public education, “The legislature shall provide, by general law, for a thorough and efficient system of free schools” (Alexander \& Alexander, 2005, p. 13). A thorough knowledge of school law issues and the ability to apply legal theory to practice is essential to the efficient administration of schools (Alexander \& Alexander, 2005; Dunklee \& Shoop, 2006; Essex, 2005; Zirkel, 1997). "Prior to understanding how their actions may result in legal action, school officials must first know what actions typically lead to litigation and know how their knowledge of the legal issues relate to those actions” (Littleton, Higham, \& Styron, 2001 p. 2).

\section{Statement of the Problem}

“The knowledge and skills required to be an effective educational leader are embedded in cognitive, pedagogic, and leadership principles” (Chapman, Parks, and Walls, 2005, p. 21). The primary research problem addressed in this study was to determine if a relationship exists among West Virginia principal's ability to accurately answer questions in five areas of school law given both knowledge level statements and application level scenarios. The cognitive complexity of the tasks is examined on two levels: knowledge and application. Knowledge level, the ability to correctly respond to statements that involves recall of facts, is a less complex cognitive task than application level, the ability to apply facts to unique situations (Bloom, Engelhart, Furst, Hill, \& Krathwohl, 1956).

The pedagogical construct of principal preparation in school law coursework was also of interest. This paper provides an historical overview and update on current trends 
for principal preparation programs. One research question allows principals to self-report regarding the pedagogical construct of their own coursework experiences by asking "The methods used to teach my school law course(s) were primarily [either] fact-based knowledge [or] case-based application.”

Leadership principles also are part of the problem examined. A critical principal competency is described in the draft of Policy 5800 - Standards of Professional Practice for West Virginia Superintendents, Principals and Teacher Leaders. The policy, an outcome of a statewide leadership collaborative, proposes the indicator Demonstrates Interpersonal and Collaborative Skills (West Virginia Department of Education [WVDE], 2010). The draft policy includes the following:

d. The principal frames problems and make decisions to promote the long-term best interest of students.

e. The principal anticipates, addresses and resolves conflict. (WVDE, 2010) The ability of a principal to recognize situations with legal implications and to accurately apply knowledge of school law to resolve unique issues that occur on a daily basis, demonstrates the competencies for this indicator, and in so doing, avoids the time and expense required to defend a faulty decision leaving more time to focus on the principal's primary mission of promoting the success of all students (Interstate School Leaders Licensure Cconsortium [ILLSC], 2008; WVDE, 2010).

\section{Purpose of the Study}

The purpose of this study was to examine West Virginia principals’ knowledge of school law and ability to apply knowledge of school law and to determine if a relationship exists among the variables studied. The study included questions about five 
areas of school law: separation of church and state, faculty issues, special education, student issues, and tort liability, and looked at selected variables that may have impacted the ability of principals to respond appropriately to legal issues encountered in school settings. Independent variables include: the school program level, e.g., elementary, middle, or high school; years of teaching; years of administrative experience; type of credentialing program; the type of school law courses taken; number of school law courses taken; and the pedagogical methodology utilized in pre-service preparation.

\section{Significance of the Study}

The overarching significance of this study is the need to effectively prepare and support principals to thoroughly and efficiently fulfill their roles as school leaders. Principals must have knowledge of relevant school law and demonstrate the ability to apply that knowledge to a variety of situations. In turn, as a principal correctly and efficiently responds to situations with legal implications, local school districts conserve valuable staff time and financial resources, and in the process, may preserve community and parent relationships.

A key function of principal leadership is indicated in the ability to accurately frame problems, to analyze causal factors, and to develop an appropriate response (WVLDSC, 2009). This study provides information about factors that may influence West Virginia principals’ demonstration of ability to correctly respond to the Williams School Law Survey items. A section of the survey provides a forum for principals to reflect on their own school law coursework, to share thoughts about needs for principal preparation programs, and to make recommendations about areas of school law for ongoing professional development. 
The study has three distinct areas of significance to stakeholders. First, results of the study may inform higher education policy and procedure regarding effectiveness of administrative personnel preparation programs as demonstrated by principal’s knowledge of school law. Second, data concerning specific areas of principal's knowledge of school law may be used as a basis for determining professional development for public school principals. Third, participation in the study was valuable to practitioners as feedback regarding knowledge and application of school law was provided as a post-survey resource.

A review of literature and relevant studies revealed a paucity of information regarding the efficacy of administrative credentialing programs and pedagogical methods, the availability of data-driven professional development related to specific areas of school law, and accessible feedback to West Virginia principals in the selected areas of school law: church-state relations, faculty issues, special education, student issues, and tort liability. Further, no current research addresses West Virginia principals’ knowledge and application of school law.

\section{Research Questions and Hypotheses}

1. Do elementary school principals, middle school principals, and high school principals have different scores in knowledge of school law and application of school law in the five areas tested: separation of church and state, faculty issues, special education, student issues, and tort liability?

$\mathrm{H}_{\mathrm{o}}$ There is no statistically significant difference when comparing scores of principals of elementary, middle, and high schools on their knowledge of school law and 
application of school law in the five areas tested: separation of church and state, faculty issues, special education, student issues, and tort liability.

$\mathrm{H}_{\mathrm{o}}$ all group mean ranks are equal

$\mathrm{H}_{\mathrm{a}}$ : Elementary school principals, middle school principals, and high school principals have different scores in knowledge of school law and application of school law in the five areas tested: separation of church and state, faculty issues, special education, student issues, and tort liability.

$\mathrm{H}_{\mathrm{a}}$ : not all the group means are equal.

2. Is there a difference in the knowledge and application of school law scores of principals in the five areas tested: separation of church and state, faculty issues, special education, student issues, and tort liability, and the number of years the principals worked as a teacher when compared by quartiles of experience?

$\mathrm{H}_{\mathrm{o}}$ : There is no statistically significant difference when comparing knowledge and application scores of principals and the quartiles of number of years principals have worked as a teacher in the five areas tested: separation of church and state, faculty issues, special education, student issues, and tort liability.

$\mathrm{H}_{\mathrm{o}}$ all group mean ranks are equal

$\mathrm{H}_{\mathrm{a}}$ : There is a statistically significant difference when comparing knowledge and application scores of principals and the quartiles of number of years principals have worked as a teacher in the five areas tested: separation of church and state, faculty issues, special education, student issues, and tort liability.

$\mathrm{H}_{\mathrm{a}}$ : not all the group mean ranks are equal 
3. Is there a difference in the knowledge and application of school law scores of principals in the five areas tested: separation of church and state, faculty issues, special education, student issues, and tort liability, and the number of years of experience as a principal?

$\mathrm{H}_{\mathrm{o}}$ :There is no statistically significant difference when comparing knowledge and application scores of principals and the quartiles of number of years principals have worked as a principal in the five areas tested: separation of church and state, faculty issues, special education, student issues, and tort liability.

$\mathrm{H}_{\mathrm{o}}$ all group mean ranks are equal

$\mathrm{H}_{\mathrm{a}}$ : There is a statistically significant difference when comparing knowledge and application scores of principals and the quartiles of number of years principals have worked as a principal in the five areas tested: separation of church and state, faculty issues, special education, student issues, and tort liability.

$\mathrm{H}_{\mathrm{a}}$ : not all the group mean ranks are equal

4. Do principals who took school law courses in a master's program in educational leadership (public school) have different scores than principals who took school law courses in an 18-hour certificate program in public school administration and principals who took their school law coursework elsewhere, in knowledge of school law and application of school law in the five areas tested: separation of church and state, faculty issues, special education, student issues, and tort liability?

$\mathrm{H}_{\mathrm{o}}$ : There is no statistically significant difference when comparing the type of program where principals took school law coursework and their knowledge of school law and 
application of school law in the five areas tested: separation of church and state, faculty issues, special education, student issues, and tort liability.

$\mathrm{H}_{\mathrm{o}}$ : all group mean ranks are equal

$\mathrm{H}_{\mathrm{a}}$ : There is a statistically significant difference when comparing the type of program principals took school law coursework and their knowledge of school law and application of school law in the five areas tested: separation of church and state, faculty issues, special education, student issues, and tort liability.

$\mathrm{H}_{\mathrm{a}}$ : not all the group mean ranks are equal

5. Do principals who took school law courses covering multiple topics in school law have different scores than principals who took school law courses dedicated purely to school law in knowledge of school law and application of school law in the five areas tested: separation of church and state, faculty issues, special education, student issues, and tort liability?

$\mathrm{H}_{\mathrm{o}}$ : There is no statistically significant difference when comparing the type of course taken in school law and their knowledge of school law and application of school law in the five areas tested: separation of church and state, faculty issues, special education, student issues, and tort liability.

$\mathrm{H}_{\mathrm{o}}$ : group mean ranks are equal

$\mathrm{H}_{\mathrm{a}}$ : Principals who took school law courses covering multiple topics in school law have different scores than principals who took school law courses dedicated purely to school law in knowledge of school law and application of school law in the five areas tested: separation of church and state, faculty issues, special education, student issues, and tort liability. 
$\mathrm{H}_{\mathrm{a}}$ : group mean ranks are not equal

6. Do principals who have taken variously one course, two courses, or three courses in school law have different scores in knowledge of school law and application of school law in the five areas tested: separation of church and state, faculty issues, special education, student issues, and tort liability?

$\mathrm{H}_{\mathrm{o}}$ : There is no statistically significant difference when comparing the number of courses taken in school law and their knowledge of school law and application of school law in the five areas tested: separation of church and state, faculty issues, special education, student issues, and tort liability.

$\mathrm{H}_{\mathrm{o}}$ : all group mean ranks are equal

$\mathrm{H}_{\mathrm{a}}$ : There is a statistically significant difference when comparing the number of courses taken in school law and principals’ knowledge of school law and application of school law in the five areas tested: separation of church and state, faculty issues, special education, student issues, and tort liability.

$\mathrm{H}_{\mathrm{a}}$ : not all the group mean ranks are equal

7. Do principals whose school law courses were taught using fact-based knowledge have different scores than principals whose school law courses were taught using case-based application in knowledge of school law and application of school law in the five areas tested: separation of church and state, faculty issues, special education, student issues, and tort liability?

$\mathrm{H}_{0}$ : There is no statistically significant difference when comparing the scores of principals with methods used to teach school law courses taken in school law and their knowledge of school law and application of school law in the five areas tested: 
separation of church and state, faculty issues, special education, student issues, and tort liability.

$\mathrm{H}_{\mathrm{o}}$ : group mean ranks are equal

$\mathrm{H}_{\mathrm{a}}$ : There is a statistically significant difference when comparing the scores of principals with methods used to teach school law courses taken in school law and their knowledge of school law and application of school law in the five areas tested: separation of church and state, faculty issues, special education, student issues, and tort liability.

$\mathrm{H}_{\mathrm{a}}$ : group mean ranks are not equal

\section{Assumptions}

It was assumed that principals answered survey questions without consulting outside resources and principals did not guess. It was also assumed that principals were familiar with terminology related to educational law issues.

\section{Limitations}

The time needed for respondents to complete the survey was a limitation as some principals began the survey but did not complete enough items needed for data analysis. A limitation of the study was the number of survey responses and the number of surveys with enough completed items. The response rate may have reduced the power of the statistical analysis - the probability of finding a difference that does exist. The use of ordinal responses meant nonparametric procedures had to be used which also might impact power. The study was limited to principals in West Virginia. 


\section{Delimitations}

Delimitation was the scope of school law knowledge topics presented in the survey. Five areas of school law were queried with an equal number in each of the five categories. School law areas addressed included separation of church and state, faculty issues, special education, student issues and tort liability. The study was nonexperimental and was primarily quantitative descriptive and causal comparative research.

\section{Organization of the Study}

This study contains five chapters. Chapter One includes the introduction, background of the problem, statement of the problem, purpose of the study, significance of the study, research questions and hypotheses, limitations, delimitations, assumptions, and organization of the study. Chapter Two includes the review of pertinent literature beginning with a history of court involvement in education law and case law. An overview of previous studies of principal knowledge of school law adds depth to the review of salient literature. The national focus on reform of principal preparation programs is integral to examination of education law in the context of educational leadership programs, leading to explanation of the three domains aligned with the theoretical framework of the study. Chapter Three describes the method used for the study including data collection and analysis. Chapter Four presents findings of the survey research including an analysis of the quantitative data and principals’ perceptions and recommendations about university preparation and professional development. Chapter Five is a discussion and summary of key findings, implications, and recommendations for future research. 


\section{Chapter Two}

\section{Review of the Literature}

This literature review begins with the emergence of laws impacting public education in America and traces development of present day education law including special education law. A review of prior studies that assess the school law knowledge of principals provides a basis for selection of question items for the assessment in this study. A national focus on principal preparation programs and the evolution of principal preparation programs provides a lens for viewing school law coursework in the frame of program delivery and pedagogy. The theoretical framework for the study and the three domains of the theoretical framework complete the review of literature.

\section{Historical Background of School Law}

Historically, founders of the United States of America were challenged to create an egalitarian system of education, the antithesis of the English class system in which educational opportunity was limited to the few (Alexander \& Alexander, 2005). Horace Mann, the renowned education reformer, articulated the American ideal that "it was reserved for 'the Fathers' to engraft that great principle in the laws of a country, as a maxim of government, that all the people of a State should be educated by the State” (in Alexander \& Alexander, 2005, p. 22). Over time, the state and local control of public education evolved to include the broader society, federal government and the courts.

Today the control of public education is a combination federal government interest and oversight through the courts, but remains a function of each state, with delegation of responsibility to local boards of education (Essex, 2006). As education has evolved, so has school law. Both legislation and legal actions have contributed to the 
current makeup of education law. Case law increasingly impacts day-to-day school operations and lends a complexity to the decisions faced daily by school administrators (Brown, Rubenstein, \& Seufer, 1999; Dowling-Sendor, 2006; Gordon, 1997).

Alexander and Alexander (2005) explain the role of precedent in judicial decisions with a translation of stare decisis et non quieta movere, "to stand by (or adhere to) decisions and not to disturb what is settled” (p. 8). The role of precedent in Alexander and Alexander continues with a discussion by Hanna from the 1957 Villanova Law Review:

The general American doctrine as applied to courts of last resort is that a court is not inexorably bound by its own precedents but will follow the rule of law which it has established in earlier cases, unless clearly convinced that the rule was originally erroneous or is no longer sound because of changing conditions and that more good than harm will come by departing from precedent. The alternative to stare decisis as popularly defined would be (1) absolute discretion on the part of a court to decide each case without reference to any precedent; or (2) complete codification of our law, with a requirement that each court look independently to the code for a basis of decision... if we define stare decisis in terms of its proper limitations, it should always be applied. (Alexander \& Alexander, 2005, p. 8) Hogan (1974) chronicles five stages of court involvement in education. The first is categorized as strict judicial laissez faire (1789-1850), leaving education to the educators. During this period, state and federal courts largely ignored education. The second stage, state control of education, (1850-1950) was a period during which state courts treated education litigation as a state or local concern. During the third stage, 
reformation (1950-1974), the Supreme Court at last acknowledged that some states’ educational practices and policies were not conforming to federal constitutional requirements. By 1950, federal courts recognized that individual rights were not being protected. The landmark court decision of the Supreme Court in Brown v Board of Education in 1954 was the beginning of federal intervention needed to remedy inadequate state systems in order to ensure quality and equity in public education (Hogan, 1974).

After the Brown decision, the federal courts expanded power over schools in areas of administration, organization, and programs, "retaining jurisdiction over cases until their mandates, orders, and decrees have been carried into effect” (Hogan, 1974, p. 6). This stage was concurrent with what Hogan labels as education under supervision of the courts. During this period, the courts established unprecedented power to retain jurisdiction and oversee cases until school systems presented evidence of compliance with court orders.

The fifth stage Hogan identifies is that of strict construction by the Federal courts. The U.S. Constitution does not mention education, thus strict constructionists construe education as a state function. Under the Tenth Amendment, “powers not delegated to the United States by the Constitution, nor prohibited by it to the States, are reserved to the States exclusively respectively or to the people” (Alexander \& Alexander, 2005, p. 67). Hogan's assessment of the judicial impact on education concludes with the 1973 Nixon Court and the landmark school finance case, San Antonio Independent School District v. Rodriguez. In that decision, the Supreme Court declared, "education is not a fundamental right under the U.S. Constitution” (Alexander \& Alexander, 2005, p. 89). Federal judges 
looked to this ruling to guide later intervention in public schools, with decisions involving individual rights, not fundamental rights, resulting in decisions that have materially shaped education in the United States (Alexander \& Alexander, 2005; Essex, 2005; Hogan, 1974, 1985; LaMorte, 2005; Slasinski-Griem, 1990).

This shift toward the individual is underscored by the advent of laws regarding educational rights of student with disabilities. Shaped in part by Civil Rights legislation with the 1954 landmark case, Brown v. Board of Education, the Supreme Court guaranteed equal protection under law to all citizens. By extension, persons with disabilities were to be afforded due process if denied life, liberty, or property (Yell, 2006).

In the early 1970s, two Supreme Court decisions affirmed the rights of students with disabilities to "have an equal right to access education as their nondisabled peers (Murdkic et al., 2007). The first case, Pennsylvania Association for Retarded Children (PARC) v. Commonwealth of Pennsylvania found that liberty and property interests were denied when a student classified as mentally retarded was excluded from public school. The case also found placement in a regular public school classroom preferable to placement in a special class setting. This principle is known today as the least restrictive environment or LRE (McEllistrem, Roth, D'Agostino, \& Brown, 2007; Yell, 2006). The second case, a class action suit, was Mills v. Board of Education of the District of Columbia resulted in a consent decree that, "No child eligible for a publicly funded education....shall be excluded from a regular public school assignment ....” (Murdkic et al., 2007). The Education for All Handicapped Children Act (EAHCA), also known as 
Public Law 94-142, was passed in 1975, mandating all school districts to educate children with disabilities (McEllistrem et al., 2007; Yell, 2006).

The Education for All Handicapped Children Act (EAHCA) was amended in 1986 and added clarity to parents' and students’ rights. The 1990 Americans with Disabilities Act mandates protections for persons with disabilities in the public and private sectors that carried over in school environments. An amendment to EAHCA in 1990, the Individuals with Disabilities Education Act (IDEA) included many changes including a requirement that transition services must be provided for students with disabilities. Further changes to IDEA were enacted in 1997 with a requirement that students with disabilities be included in state and district assessments. Regular education teachers were required to be members of Individual Education Plan (IEP) meetings for all students with disabilities (McEllistrem et al., 2007; Wright \& Wright, 2005; Yell, 2006).

Developments in the new century continued to raise accountability for the education of students with disabilities. A significant development was the 2001 No Child Left Behind (NCLB) law calling for all students, including students with disabilities, to be proficient in math and reading by the year 2014. The reauthorization of IDEA in 2004 became the Individuals with Disabilities Education Improvement Act (IDEIA) and included comprehensive guidelines concerning discipline of students with disabilities, a definition of homeless children, limited English proficient, and parent. The law added nursing and interpreting services to related services, expanded the focus of transition services to improve academic and functional achievement, and emphasized the use of research-based services (Yell, 2006). 


\section{Relevant Studies}

A comprehensive study, Educating School Leaders (Levine, 2005), reports 91\% of principals have taken courses in school law and notes, "principals put a premium on classes they had taken that were most relevant to their jobs” (p. 28). Principals rated school law as having the highest relevance and value related to their job of any coursework taken in their principal preparation programs (Levine, 2005). Despite the assertion school law coursework had high relevance, substantial evidence suggests principal preparation programs are inadequate in preparing aspiring principals for legal issues faced daily (Brabrand, 2003; Caldwell, 1986; Davis, Darling-Hammond, LaPointe, \& Meyerson, 2005; Littleton et al., 2001 ; Schlosser, 2006; Schlosser \& Littleton, 2006).

\section{Prior Studies of Principals’ Knowledge of School Law}

Previous studies have examined principals’ knowledge of school law. The studies, primarily doctoral research, have been conducted in the past three decades, scattered across 28 states. Brabrand (2003), Littleton and colleagues (2001) and Schlosser (2006) include summaries of school law studies in their research. Littleton notes, "There is a paucity of recent research since 1990 describing the levels of knowledge school officials have of legal issues affecting public schools” (Littleton et al., 2001 p. 2).

Early relevant studies, dating from 1983 to 1997 include Stephens (1983), Caldwell (1986), Kerrigan (1987), Clark (1990), Osborn (1990), Reglin (1992), Daley (1993), Singletary (1996), and Gordon (1997). The most comprehensive of those studies was that of Stephens, who developed a national study using Supreme Court cases gleaned from Zirkel’s 1978 book, A Digest of Supreme Court Decisions Affecting Education (in 
Schlosser, 2006, p. 25). Stephens presented 30 hypothetical cases directly or indirectly related to principals’ responsibilities. The research study included principals from all fifty states and the District of Columbia and every state’s department of education. All state departments of education responded to a question regarding a requirement that principals have at least one school law course in order to be certified as a principal. Only 12 states had that requirement, with only two states requiring two courses in education law. Stephens (1983) recommended that all states require coursework in school law as a requirement for principal certification.

Caldwell’s 1986 study, Virginia Principals and School Law, the precursor for Brabrand's 2003 study, included a 40-item true or false test of legal knowledge. The survey questionnaire included four areas of school law: student rights, teacher and administrator issues, church and state relations, and tort liability. The range of scores was $47.5 \%$ to $95 \%$ with an average score of $78.1 \%$. Of those surveyed, Caldwell found the principals to have "adequate or average knowledge of school law" (p. 77). Among Caldwell's recommendations was “The same study should be conducted in other states” (p. 77).

A 1987 study was conducted in Massachusetts (Kerrigan). The study consisted of statements based on both educational law policy and the role of administrators as school principal. Disconcerting results revealed that principals did not know if their school system had policy guidelines, if a policy handbook existed in their district, or if policy were based on state law or developed within the districts. The study concluded that principals exhibited a need for more information regarding educational law policy (Kerrigan, 1987). 
A study in South Dakota (Osborn, 1990) utilized a 40-item school law survey. An average score of $72 \%$ was felt to represent only a fair knowledge of school law. Elementary principals scored significantly lower than secondary principals (Osburn, 1990).

A Mississippi study (Clark, 1990) utilized scenarios to address knowledge of student rights including freedom of expression, search and seizure, suspension and expulsion, school attendance, corporal punishment, child abuse, special education, school vandalism, child custody and religion. Clark found that principals had only marginal knowledge of school law issues presented in the research questionnaire.

South Carolina State College (Reglin, 1992) conducted a study that included educators, assistant principals and principals. A 15-item questionnaire included church and state issues of prayer in school, Bible reading, student rights, tracking, exit examinations, school finance, issues regarding students with disabilities and corporal punishment. Findings included 38\% of principals and assistant principals did not take graduate education law coursework. Reglin recommended staff development for principals in specific areas of school law.

Schlosser scrutinized Daley’s 1993 Virginia study that assessed school law knowledge on sexual misconduct. Tort liability was presented in ten scenarios pertaining to negligence. Each scenario represented actual cases. Both teachers and principals participated in the survey (Daley, 1993). Only 35\% of the principals scored at least 70\% with a finding that principals who had taken school law coursework "were more likely to achieve a higher score on the research instrument” (Schlosser, 2006, p. 27). 
Both Brabrand and Schlosser looked at research conducted by Gordon in West Virginia (1997). Gordon, "had an interest in the area of school law" (H. Gordon, personal communication November 20, 2006) and conducted a survey of secondary principals in West Virginia to "serve as baseline information for developing statewide seminars and workshops for prospective secondary school principals” (Gordon, 1997, p. 2). Findings presented at the West Virginia "Supervising Teacher’s Conference” (1997) concluded, “This finding suggests respondents in this study had an average preparation in school law” (p. 7) and “a need for the state of West Virginia to develop inservice programs to update principals’ legal knowledge” (p. 8).

A Mississippi study (Singletary, 1996) used the Legal Knowledge Survey from the Clark (1990) study. Both studies were conducted in Mississippi. A recommendation again surfaced that "there was a need for annual school law staff development programs for all principals and school level administrators” (Brabrand, 2003, p. 19).

A Virginia study, Kalafatis (1999), examined only the area of search and seizure. With a set score of 29 of 40 to represent minimum competency, only 35\% of respondents were able to demonstrate that minimum. Kalafatis recommended inclusion of more school law coursework at both the undergraduate and graduate levels and professional development with emphasis on school law (Kalafitis, 1999).

More recent studies of principals’ knowledge of school law have focused in Virginia (Brabrand, 2003; DiPaola \& Walther-Thomas, 2003) and Texas (Littleton et al., 2001 ; Schlosser, 2006; Schlosser \& Littleton, 2006). Brabrand’s doctoral study, Virginia Principals and School Law found principals displayed a fair knowledge across all categories of law. Brabrand (2003) also found that "principals who received their legal 
preparation more than 10 years ago scored significantly lower on the tort section of the test than those who received their legal preparation only 5-10 years ago” (p. ii).

The College of William and Mary (DiPaola \& Tschannen-Moran, 2001) with grants from the Virginia Department of Education, the Virginia Association of Secondary School Principals, and the Virginia Association of Elementary School Principals, conducted a comprehensive study of Virginia principals $(n=1666)$. The study identified problems and issues in organizational management with $87.9 \%$ of the respondents identifying legal issues as significant (50.6\%) or highly significant (37.2\%). More than 70\% identified an average to high need for professional development concerning legal issues (DiPaola \& Tschannen-Moran, 2001, p. 13).

Schlosser (2006) scrutinized three studies of principals’ knowledge of school law. The studies were conducted in Texas and assessments were given to preservice and practicing principals. Results of all three studies were "consistent with the majority of other studies that found school leaders’ knowledge of school law inadequate” (p. 28).

Administrators vary in preparation with some having completed certificate programs and others having advanced degrees. Previous studies of principals’ knowledge of school law (Brabrand, 2003; Caldwell, 1986; Clark, 1990; Daley, 1993; Kalafitis, 1999; Kerrigan, 1987; Littleton et al., 2001; Osburn, 1990; Schlosser, 2006; Singletary, 1996; Stephens, 1983) included variables of administrative service and the programmatic level, i.e., elementary, middle, or high school (Larry, 2006).

The study Virginia Principals and School Law concludes "principals across all categories of school law displayed only a fair knowledge of school law” (Brabrand, 2003, p. ii). Further, Schlosser and Littleton compared twenty-nine research studies in fifteen 
states. Only three of the twenty-nine studies had findings that principals showed adequate knowledge of school law. Researchers in the other twenty-six studies "found gaps and recommended additional training in school law knowledge” (Schlosser \& Littleton, 2006, p. 3). School law is a narrow, but essential, aspect of principal preparation programs. In an era of increased accountability in education, the principal as school leader is the focus of scrutiny as critics point to shortcomings in public education (Hess \& Kelly, 2005; Levine, 2005).

\section{Prior Studies of Principals’ Knowledge of Special Education Law}

Studies specific to special education law reveal a need for explicit instruction in the legal requirements surrounding special education (Bravenec, 1988; Copenhaver, 2005; Hirth, 1988; Magone, 2007; Power, 2007; Witt, 2003). Bravenec conducted a critical needs survey of 200 elementary and secondary school principals in Texas. The study examined administrator preparation and administration of special education programs and included a survey of the amount of time principals dedicated to special education issues. Alarmingly, more than two decades ago, principals reported a range of $25 \%$ to more than $75 \%$ of time spent daily in activities related to special education. At the time of the study, Bravenec concluded that university preparation for principals should include special education law (Bravenec, 1988).

Hirth (1998) surveyed Tennessee principals’ knowledge of special education law. Hirth found that participants had an overall score of $72 \%$ and concluded principals did not display the sufficient degree of knowledge needed to ensure compliance with special education law, particularly in areas of procedural safeguards and provision of a free appropriate public education. 
Witt (2003) conducted a study of university principal preparation programs. A survey of 94 department chairs of educational administration programs across the nation solicited opinions on a number of topics including special education issues and instruction at the graduate level. Witt found coursework in school law is the primary means with which preparation programs address special education issues. However, less than $12 \%$ of the responding institutions include a requirement that principal candidates take a law course specific to special education. Among recommendations from the study was principal preparation programs should include both a general and special education law course requirement. Witt also asserted assessments for licensure of principals should include competency in the legal aspects of special education (Witt, 2003).

Copenhaver (2005), in a study similar to Hirth’s, utilized a 30-question, true/false/not sure questionnaire to study North Carolina principals’ knowledge of special education law. The 350 respondents scored an overall $68 \%$ on the questionnaire. Among study findings, principals with more experience, (6-10 years) scored higher than principals with less experience (1-5 years). Copenhaver raised concerns regarding principals' knowledge of special education law, particularly in the area of "procedural safeguards” (p. 132). Copenhaver's recommendations included a need for improvements in principal preparation with regard to special education law at the university, district, and individual levels.

Magone (2007) conducted an extensive study in Montana that included public school principals, superintendents, and attorneys specializing in school law, with 268 total responses to reflect a confidence interval of $95.6 \%$. The study reflected consensus among participants regarding the importance of inclusion of broad range of school law 
topics to be included in university preparation programs, including topics concerning exceptional children, student issues including harassment, student suspensions and expulsions, and staff issues including dismissal procedures. Magone’s investigation concluded principal preparation programs should include “a broad base of school law topics” (p. ii.). The study found most respondents perceived an administrative colleague as "the most highly preferred and used source of school law information” and “an overwhelming majority (96\%) of the respondents agreed school law curriculum and content alignment among school law providers was needed” (Magone, 2007), p. ii).

Power (2007) surveyed a sample of principals in Virginia using scenarios to determine the degree with which principals could apply special education law to specific situations. The Power study consisted of a representational geographic sample with 462 principal participants. An on-line survey of 24 hypothetical scenarios included specific areas of special education law: free and appropriate public education, due process, individualized education plans, least restrictive environment, related services, student discipline and liability for reimbursement of parents. Results of the Power study did not find a significant difference between principals' test scores and any of the ten demographic variables. The study identified related services and provision of free, appropriate public education (FAPE), to be areas of significant weakness.

\section{National Focus on Principal Preparation Programs}

This review of literature, focused generally on literature and studies of principal knowledge of school law, has at its core the curricula and programs that prepare principals. The purpose of all school leaders is ultimately to enhance and improve student learning and success. As results of student learning assessment have come under scrutiny and criticism, so have the programs producing school leadership (Lashway, 
2003; SREB, 2006). A brief overview of efforts to improve principal preparation programs is warranted to further frame the issues investigated in the review of literature.

During the past century, educational leadership programs have endured close scrutiny with distinct periods of reform. Standards for leadership training continue to evolve in response to the changing legal landscape in education. It is timely to examine the relationships of types of administrative programs, length of service, and the programmatic level where principals demonstrate the ability to apply knowledge of school law to scenarios and correctly identify factual statements.

The American Association of School Administrators set forth recommendations in 1982 as guidelines for administrator preparation programs. Three major areas were identified: (a) seven leadership outcome goals; (b) seven competencies and related skills; and (c) five management system components, seven clinical components, and professional growth and renewal components. This document served as an impetus for curriculum and program reform and opened dialogue among constituents regarding the future of principal preparation programs (Hardin, 1998).

Other professional associations and stakeholders in the reform movement responded with their own guidelines. The National Association of Secondary School Principals listed eight essential skill areas needed for administrator effectiveness: problem solving, decisiveness, organizational analysis, leadership, sensitivity, stress, tolerance, and communication. The National Policy Board for Education Administration developed nine major objectives in the areas of organizational theory, school improvement, research leadership, and policy development and analysis (Hardin, 1998). 
The Danforth Foundation (Milstein, 1993) expended considerable resources to foster partnerships and collaboration between universities and public schools as a means to enhance preparation of educational leaders. A cohort model was utilized in cycles, beginning in 1987, and had positive outcomes for participants including collegial support, opportunity for critical reflection, and group decision making and problem solving. The model stressed student engagement and incorporated guest speakers and seminars. The positive impact of the Danforth project is evidenced by utilization of many of the project components in preparing successful leaders today (Elmore, 2000; Hess, 2004; Milstein, 1993; Portin, Schneider, DeArmond, \& Gundlach, 2003).

Principal preparation programs must provide appropriate coursework in education law so principals are prepared to recognize situations requiring application of their knowledge of school law. The National Policy Board for Educational Administration, the Educational Leadership Constituent Council (Wilmore, 2002), and the National Council for the Accreditation of Teacher Education standards for programs in educational administration acknowledge the importance of standardized expectations for principal preparation programs (P. E. Chapman, personal communication, March 21, 2007).

\section{Evolution of Principal Preparation Programs}

Preparation of school administrators has changed over time from simple and idealistic to increasingly complex. Four distinct Eras are described to characterize chronological development of school administration programs, the Ideological Era (18201900); the Prescriptive Era (1900-1946); the Scientific Era (1947-1985) and the Dialectic Era that continues today (Murphy, 1993). 
Prior to 1900, school administrators did not participate in formal preparation programs for school management. School leaders were apparently selected on the basis of character and ideology. Within 50 years, 125 institutions offered preparation programs for school administrators and a shift to trained administrators was underway. These programs drew heavily from superintendents, at the time generally white males, who joined college faculties. This period, the prescriptive era, ended with a movement to reflect a preference for adherence to "dominant social and cultural forces... as desirable alternatives for training educational leaders” (Murphy, 1993, p. 3) to characterize the new role as that of a social agent. As critics of programs agitated for change, a shift from the highly technical aspects of administration to the theoretical and conceptual material from social sciences gained momentum.

The dialectic era provided a forum for exploration of alternative approaches to structure of leadership programs (Murphy, 1992). Examination of the current state of principal preparation programs yielded critical analysis of student recruitment and selection, program content, and delivery systems. Concurrently, the application of business and social science models for building educational administration curricula was meeting with resistance (Calabrese, 2002; Milstein, 1993; Murphy, 1993). Rising to address this challenge, theories of educational leadership programs emerged, including the model used in this study.

\section{Theoretical Framework}

“The knowledge and skills required to be an effective educational leader are embedded in cognitive, pedagogic, and leadership principles” (Chapman et al., 2005, p. 21). Based on that premise, Chapman et al. provide a theoretical model for developing 
educational leadership preparation programs (see Figure 1). Their triangular model

provides a framework to examine school leaders in relation to cognition, pedagogy and leadership.

This study adapted the model, replacing the central figure, the educational leadership student, with educational leaders, i.e., West Virginia principals. Use of this model provided a frame of inquiry encompassing three domains: cognition, pedagogy, and leadership. The research survey in this study addressed those three domains in its design and objectives. The instrument assessed two levels of cognition: knowledge and application. The survey also examined the type of administrative certificate program attended by participants and pedagogical practice utilized in participants' administrative programs. Demographic information provided a frame for a descriptive overview of variables related to leadership, as effective principal leaders must be able to correctly apply tenets of education law in order to comply with their charge to manage schools thoroughly and efficiently. Figure 1 is used to illustrate the building blocks of educational leadership preparation programs. 


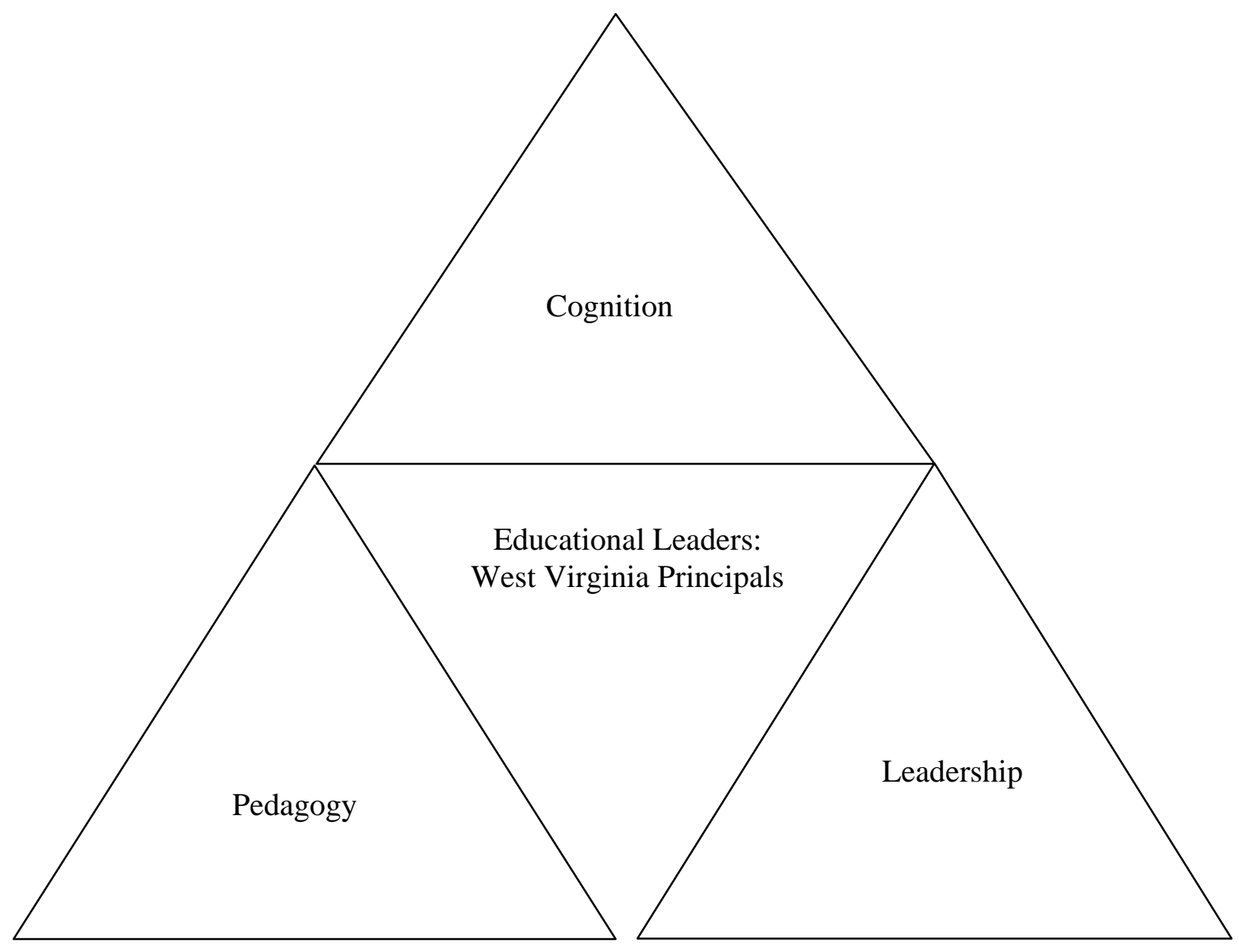

Figure 1. The building blocks of educational leadership preparation programs. Adapted from "The Building Blocks for Preparing Good Educational Leaders in Troubled Times,” by Paul E. Chapman, David J. Parks, and Richard T. Walls, 2005, National Forum of Applied Educational Research Journal, 19, p. 34. Adapted with permission of the authors.

The use of theory to frame research is supported by the National Commission on Excellence in Educational Administration with a call issued in 1987 to recommend emphasis in principal preparation programs be placed on theory, clinical knowledge, applied research, and supervised practice (Green, 2001; Murphy, 1993). The Danforth 
Project (Milstein, 1993), a comprehensive effort to reform education leadership programs nationwide, also recommended use of theory and research results to bolster programming.

\section{Domains of Principal Leadership}

Principals, the leaders of schools, are in great part, shaped by the framework of their principal preparation programs. Chapman et al. (2005) advocate for three general concepts to frame principal preparation programs. The authors ask and answer the question of how cognition, pedagogy, and leadership may be incorporated as building blocks to shape educational leaders.

Cognitive domain. Scholars familiar with the levels of cognition first think of Bloom’s Taxonomy, a seminal work first published a half century ago (Bloom et al., 1956). Bloom and colleagues categorized learning in a hierarchal fashion with knowledge, a low level of cognition, characterized as recall of facts, basic concepts and answers. Application, a higher level in the hierarchy, may be described as the ability to apply facts to new situations in order to problem solve.

Recently revisited, the levels of Bloom's taxonomy have been reframed with the use of more active verbs in place of nouns and new categories of knowledge (Anderson et al., 2001). Knowledge is described as a verb, to know, and represents the cognitive process of recall of facts. Knowledge as a noun refers to the dimension and would be termed factual. The recall of factual information is now incorporated as the first major category of the knowledge dimension, including familiarity with terminology and specific details. Similarly, to apply knowledge involves the cognitive complexity needed to use knowledge in a particular situation or scenario. Application may now be viewed in 
the knowledge dimension as procedural knowledge, including subject specific skills and use of appropriate responses to problem solve (Anderson et al., 2001).

Bloom's taxonomy of cognition provides a theoretical framework for examination of principals’ abilities to correctly identify factual statements of education law compared with the higher level of cognition involved in application of knowledge for solving problems. Another theory germane to this research is a theoretical model for developing educational leadership preparation programs proposed by Chapman, Parks, and Walls (2005). This model utilizes a framework encompassing three domains: cognition, pedagogy, and leadership to guide effective and efficient leadership of schools.

Pedagogic domain. Much attention has been given to curriculum reform in an effort to more fully engage learners to reach meaningful outcomes (Jones, 2002). Chapman et al. (2005) propose, “The best way to help people overcome problems presented to them by society and the world at large is by allowing them the opportunity to have the experiences to heighten their awareness and build their knowledge” (p. 25). Principal preparation programs are advised to incorporate teaching and learning theory in programming and focus on modeling pedagogic practice with an outcome of enhancing awareness, knowledge, and coping skills for future educational leaders.

Leadership domain. Leadership is "what effective leaders do as they go about the business of running their schools, departments, or districts” (Chapman et al., 2005, p. 31). The National Policy Board for Educational Administration (2002) developed Standards for Advanced Programs in Educational Leadership for principals, superintendents, curriculum directors and supervisors. Standard 3.0 states, “Candidates who complete the program are educational leaders who have the knowledge and ability to 
promote success of all students by managing the organization, operations, and resources in a way that promotes a safe, efficient, and effective learning environment” (National Policy Board for Educational Administration, 2002, p. 3).

Effective and efficient school leadership includes the abilities of principals to demonstrate knowledge of legal principles governing efficient and thorough schools, and to demonstrate the cognitive complexity necessary to correctly apply legal knowledge to practice. The principal must be cognizant of situations with legal implications that require immediate and appropriate action. The relationship between that ability to apply school law appropriately may have a relationship to pedagogical practices as perceived and reported by practitioners. Using this model, West Virginia school principals replace the leadership student as the central element of the model. The peak of the triangle, leadership, includes the demonstrated ability of surveyed principals to correctly answer application and factual survey questions. Cognition is applied to the domain of principal preparation program and pedagogy is applied to responses describing aspects of educational leadership coursework.

Walls, a co-author of The Building blocks for Preparing Good Educational Leaders in Troubled Times, (Chapman, et al., 2005) has compiled a list of desirable pedagogical practices to be included in leadership programs. Stressing that principal preparation programs serve adults, Walls advises faculty in leadership programs to be familiar with characteristics of adult learners. Further, Walls advocates, "Student learning is better when instructors ask questions and give feedback rather than lecture for extended periods of time... when instructors make independent work varied and 
interesting enough to motivate student engagement....” (Chapman et al., 2005, pp. 2627).

Increasing litigation regarding school issues, combined with the time and financial cost of litigation, underscores the importance of adequate and useful school law curricular offerings in higher education principal preparation programs. Significant changes in education law, resulting from Supreme Court decisions in the last quarter century, focus on employee issues, teacher and administration issues, church and state relations, and student rights (Brabrand, 2003; Caldwell, 1986; DiPaola \& TschannenMoran, 2001; DiPaola \& Walther-Thomas, 2003; Dowling-Sendor, 2006; Murdkic et al., 2007; Wright \& Wright, 2005; Yell, 2006).

The Stanford Educational Leadership Institute notes the job requirements of the principal “... far exceed the reasonable capacities for any one person” (Davis et al., 2005, p. 3). Regardless of that assertion, principals in West Virginia schools must be proficient in recognizing aspects of situations that involve knowledge of education law, and more importantly, must be able to apply knowledge to the complex scenarios played out daily in school settings. 


\section{Chapter Three}

\section{Method}

This study was primarily quantitative and included qualitative elements in order to provide germane reflection and recommendations by participants. Data analysis of quantitative research questions yielded descriptive and causal comparative findings. This study was nonexperimental and no control of independent variables was attempted. All research questions involved use of nonparametric measures to examine the relationship of seven independent demographic variables to the scores of principals on survey items on questions about five categories of school law. Nonparametric tests were conducted to determine group differences in school law scores across demographic groups. The Kruskal-Wallis test was used to analyze data from independent variables. When significant differences were found, independent variables were paired for subsequent testing using the Mann-Whitney U test.

A four-part web-based survey questionnaire was used to gather data. Part one included self-report for seven independent variables. Part two presented scenarios representing five areas of school law, allowing principals to apply knowledge of school law, given a choice of two responses. Part three presented fifteen statements representing the same five areas of school law, allowing principals to demonstrate recall of factual knowledge, given a choice of true or false. Part four consisted of four items for constructed responses, allowing principals to explain likes/dislikes of university level school law coursework, recommendations for university preparation, recommendation for professional development, a checklist for areas of school law that would best benefit 
principals’ professional development, and suggestions for other areas of school law needed for professional development.

\section{Population}

The population for this study consisted of all principals in public schools in West Virginia (N=704). Currently in West Virginia, there are 418 elementary principals, 163 middle school principals, and 123 high school principals (WVDE, 2009). The list of email addresses used for this research was compiled from publicly available information on the West Virginia Department of Education county and school websites.

\section{Survey Design}

The Williams School Law Survey was designed to include five areas of school law: separation of church and state, faculty issues, special education, student issues, and tort liability. An extensive review of literature revealed several studies of school law utilizing survey research. Permission was obtained to use selected items from previous surveys, augmented by questions designed by this researcher. All survey items, including those constructed by the researcher, were sent to an expert review panel to be assessed for readability and content validity.

Members of the expert panel were H. E. Seufer, Jr, an attorney specializing in school law with the West Virginia law firm Bowles Rice McDavid Graff and Love; J. E. Taylor, professor of law at West Virginia University; K. B. Larry, EdD, Executive Assistant to the State Superintendent, West Virginia Department of Education; and L. DePriest, PhD, Executive Director of Special Education, Metropolitan Nashville City Schools and adjunct faculty at Vanderbilt University. 
The reviewers were asked to rate the survey and provide suggestions for change (see Table 1). Members of the expert panel suggested changes to ensure the readability of questions. The content validity was affirmed as all reviewers agreed the survey questions addressed the area of school law as designated, tested principal's ability to apply knowledge of school law, and tested principal's ability to demonstrate factual knowledge of school law.

Table 1

Questions for Expert Panel for Readability

\begin{tabular}{|c|c|c|c|}
\hline Readability & Yes & No & $\begin{array}{l}\text { Specific problems } \\
\text { you found: }\end{array}$ \\
\hline
\end{tabular}

1. Are the questions written as to be uniformly understood?

2. Do any of the questions contain abbreviations or unconventional phrases?

3. Are any of the questions too vague?

4. Are any of the questions biased?

5. Are any of the questions objectionable?

6. Are any of the questions too demanding?

7. Do any of the questions embody a double question?

8. Do any of the questions contain a double negative?

9. Are the answer choices mutually exclusive?

10 . Do any of the questions assume too much

knowledge on the respondent's part?

Note. "Readability” from Smith, M. L., \& Glass, G. (1987). Research and evaluation in education and the social sciences. Englewood Cliffs, NJ: Prentice-Hall, p. 248.

\section{Procedures for Data Collection}

Publicly available information from West Virginia Department of Education county and school websites was used to compile a list of email addresses for public school principals. All West Virginia public school principals were emailed a cover letter 
with instructions needed to complete the web-based survey, information that participation was voluntary, that all responses would be anonymous, and an option to have to be removed from further emails (Appendix A). An attachment contained a letter of support for the study from the State Superintendent of Schools, S. L. Paine, EdD (Appendix B). Participants could opt not to participate by simply not clicking the link. The West Virginia University Institutional Review Board for the Protection of Human Subjects reviewed and acknowledged the study (Appendix C).

The letter included a highlighted and underlined direct link to the survey. The introduction to the survey also explained at the end of the survey, selection of the “DONE” button would download responses to a secure online database. After selecting “DONE,” respondents were automatically sent to a separate webpage and given the option to request a postsurvey resource to be provided at the conclusion of the study. This resource was established in an effort to increase the survey response rate.

The Williams School Law Survey was a four-part web-based survey questionnaire (Appendix D). Part one included self-report for seven selected independent variables: programmatic level of the school (elementary, middle, high); experience as a teacher; experience as an administrator; type of credentialing program; type of school law course taken; number of school law courses; and reported pedagogical construct of course delivery as fact-based knowledge or case-based application.

Part two presented scenarios representing five areas of school law, allowing principals to apply knowledge of school law, given a choice of two responses. Part three presented fifteen statements representing the same five areas of school law, allowing principals to demonstrate recall of factual knowledge, given a choice of true or false. 
Part four included four items for constructed responses, allowing principals to explain likes/dislikes of university level school law coursework, recommendations for university preparation, professional development, and a checklist for areas of school law that would best benefit principals’ professional development.

\section{Variables}

The research questions in this study involved seven independent variables. Research question one determined the programmatic level of the principal's administrative role: elementary, middle, secondary/vocational. Research question two was how many years the respondent worked as a teacher. Research question three was how many years the respondent worked as a principal or other administrator. Research question four indicated the type of program in which school law coursework was taken: an 18-hour certificate program, master's program or undergraduate or doctoral level course. Research question five indicated the type of school law course taken: 3-hour course dedicated to school law only or 3-hour course addressing multiple topics with school law. Research question six asked how many school law courses were taken. Research question seven described whether the method used to teach school law coursework was primarily fact-based knowledge or case-based application.

This study had dependent variables of principal's survey questionnaire scores in two areas (application and knowledge) in five specific categories of school law: separation of church and state, faculty issues, special education, student issues, and tort liability. 


\section{Validity and Reliability}

"Planning research requires many decisions that ultimately will bear on the quality of data collected and the credibility of the findings,” (Locke, Silverman, \& Spirduso, 1998, p. 116). Internal validity is a measure of whether research answers the questions it was designed to examine and ensures that data collected can answer the questions being asked. External validity is the extent to which a finding applies, or can be generalized, outside the study. Reliability is the degree to which an instrument measures the same way each time it is used under the same condition with the same subjects. A measure is considered reliable if a person's score on the same test given twice is similar.

The survey instrument was comprised of five areas of school law with three examples from each area. All items were reviewed for content validity and for relationship to legal references (Appendix E). Survey questions were written by the author, used with permission, or adapted from previous studies by Littleton (2001), Brabrand (2003), Schlosser (2006) and Power (2007) (see Appendices G-J). An expert panel for content validity reviewed survey questions written by the author for this study. Survey items written by the research include three knowledge level items to address special education issues and

The Littleton study, Analysis of Legal Knowledge of School Officials in Texas, utilized scenarios based on case law with particular attention to construct of items that represented a discrete area of school law. Respondents selected a response, demonstrating the ability to apply knowledge of school law. Littleton's survey instrument, consisting of scenarios, was presented to a panel of graduate students and 
professors at Tarleton State University. A factor analysis was conducted to confirm that each construct was independent (Littleton et al., 2001 ). An expert panel reviewed the instrument to ensure internal validity. Four scenarios from the Littleton study were used or adapted for use in the Williams School Law Survey. Items from the Littleton study addressed faculty freedom of expression, student freedom of expression, and two areas of tort liability.

Brabrand's dissertation, Virginia Principals and School Law (2003), included a school law survey similar to Caldwell’s 1986 study. Brabrand presented forty statements representing one legal issue and respondents were required to decide if statements were true or false. Correct answers demonstrated the respondent's cognitive ability to recall specific facts. Brabrand submitted survey questions to a panel of professors and practitioners of school law in order to assess content and construct validity. A pilot study assessed relevance and appropriateness of the instrument to school level administrators. Twelve questions from the Brabrand survey were used or adapted for use as knowledge level survey items in the Williams School Law Survey. Questions selected involved church and state issues, faculty issues, student issues and tort liability. The Brabrand survey did not address topics in special education. Three knowledge level questions were included in order to address important legal issues in special education, free appropriate public education (FAPE), least restrictive environment (LRE) and related services.

Schlosser, a research colleague of Littleton, conducted a survey as the basis for research presented in the dissertation, An Analysis of Principal Interns’ Legal Knowledge and Legal Instruction in Principal Preparation Programs (2006). Schlosser had permission to use or adapt items from Littleton's 2001 survey. The survey utilized 13 
questions adapted from Littleton’s survey and Schlosser authored two additional questions. The Williams School Law Survey includes two application level scenarios used or adapted from the Schlosser survey to address legal issues in church and state student search and seizure.

Power's dissertation, A Study of Selected Virginia School Principals’ Knowledge of Special Education Law (2007), study focused exclusively on special education law with presentation of scenarios and selection of the legally correct response. Construct validity was insured as an expert review panel examined and critiqued the survey items and construct validity. Two pilots of the survey provided direction for revisions, including correction of legal terminology and whether items addressed only one issue. The Power survey was reviewed by a Virginia attorney who specializes in school law, K. Mehfoud (Power, 2007). One item in the Williams School Law Survey was adapted from the Power survey, an application level scenario to address least restrictive environment (see Appendix D). 


\section{Chapter Four}

\section{Research Findings}

The purpose of this study was to determine if a relationship exists among principals’ ability to accurately answer school law questions given knowledge level statements and application level scenarios using seven selected independent variables: level of the school, experience as a teacher, experience as an administrator, type of credentialing program, type of school law course taken, number of school law courses taken, and reported pedagogical construct of course delivery.

A four-part web based survey questionnaire was used to gather data. Part One included self-report for seven independent variables. Part Two presented scenarios representing five areas of school law, allowing principals to apply knowledge of school law, given a choice of two responses. Part Three presented fifteen statements representing the same five areas of school law, which allowed principals to demonstrate recall of factual knowledge, given a choice of true or false. Part Four consisted of four items for constructed responses, allowing principals to explain likes/dislikes of university level school law coursework, recommendations for university preparation, recommendation for professional development, and a checklist for areas of school law that would best benefit principals’ professional development.

This chapter presents findings for both quantitative and qualitative responses to the online questionnaire survey, the Williams School Law Survey. Seven research questions and possible relationships among the levels of each independent variable with regard to the dependent variables were analyzed. The study sought to ascertain whether knowledge and application of school law, particularly in separation of church and state, 
faculty issues, special education, student issues, and tort liability, varied across demographic factors among school principals. The survey also collected information from principals about teaching styles in university principal preparation programs and recommendations for university preparation and professional development in school law.

Survey data was collected electronically. Principals received an email with a link to an online survey. Due to technical issues, including over-quota inboxes, 28 messages were undeliverable after at least three attempts. Thus, the number of principals receiving emails was reduced from 704 to 676 . The number of principals who answered at least some survey items was 322 (48\%).

Almost 20\% (63 of 317) of the respondents who answered demographic information in Part One did not answer a sufficient number of questions to be included in the results. Sixty more principals started the survey than completed the survey, including $17 \%$ of the elementary principals, $20 \%$ of the middle school principals, and $22 \%$ of the high school principals.

The number of principals who answered survey items without any missing data was 257 of 322, dropping the overall survey response rate of delivered surveys to $40 \%$. Principals who completed the needed questions included 136 of 390 at the elementary level for a response rate of 34\%, 59 of 147 at the middle school level for a response rate of 38\%, and 62 of 111 at the high school level for a response rate of 53\%.

Nonparametric tests - statistical tests designed for use when the distribution of data being analyzed does not approximate a normal curve - were utilized to analyze data from survey participant responses. Seven research questions to determine whether or not knowledge and application of school law in the five school law areas varied across 
demographic factors were analyzed using the Predictive Analytics Software (PASW).

Frequency distributions and descriptive statistics of the demographic factors and scores in school law areas were tabulated. Findings involving significant differences in school law knowledge and application for each independent variable (i.e., demographic factor) are presented after a restatement of the research question and hypotheses. Qualitative results - principals’ explanations of likes/dislikes concerning university level school law coursework, their recommendations for university preparation, recommendations for professional development, and a checklist for areas of school law that would best benefit principals’ professional development - are presented last.

\section{Description of Demographics and Study Variables}

Frequency distributions and descriptive statistics of study variables are presented in Table 2. Of 322 respondents in the study, 257 respondents completed the survey in its entirety. While the percentage of high school principals' returns was the largest category, the majority of respondents in the sample were elementary school principals (52.9\%) because there are more elementary principals than either middle or high school principals in West Virginia. Middle school principals (23\%) and high school principals (24.1\%) comprised the remainder of the respondents.

The majority of the respondents took school law coursework in a master's program in educational leadership (74.3\%); less than a quarter of respondents received school law training in an 18-hour certificate program in public school administration (20.6\%); and others took courses as part of their undergraduate or doctoral coursework (5.1\%). Participants’ school law courses were either dedicated to school law only (59.9\%), or covered multiple topics including school law (40.1\%). Most participants 
took only one course in school law (69.6\%). A quarter of the respondents reported having taken two courses in school law (25.3\%) with the remainder having taken three courses in school law (5.1\%). More students reported the pedagogical construct of school law coursework to have used a case-based approach (57.2\%) than a knowledgebased approach (42.8\%). The average Williams School Law Survey participant had 15.84 years of experience as a teacher and 11.87 years of experience as a principal.

Table 2

Frequency Distributions and Descriptive Statistics of Demographic Factors $(n=257)$

\begin{tabular}{lcc}
\hline Variable & Frequency & Percentage \\
\hline School Type & 136 & 52.9 \\
Elementary & 59 & 23.0 \\
Middle School & 62 & 24.1 \\
High School & & \\
Program & 191 & 74.3 \\
Master's & 53 & 20.6 \\
Certificate & 13 & 5.1 \\
Other & & \\
Course & 154 & 59.9 \\
Dedicated & 103 & 40.1 \\
Multiple & & 69.6 \\
Law Courses & 179 & 25.3 \\
One & 65 & 5.1 \\
Two & 13 & \\
Three & & 57.2 \\
Methods & 147 & 42.8 \\
Case-based & 110 & SD \\
Fact-based & Mean & 7.863 \\
\hline Variable & 15.84 & 8.173 \\
\hline Number of Years as Teacher & 11.87 & \\
Number of Years as Principal & & \\
\hline
\end{tabular}

A score summary in each of the five areas of school law is presented in Table 3. In examining scores in each area on knowledge and application of school law, the questions involving separation of church and state had the lowest average of correct 
responses with a mean score of 4.14 of 6 items answered correctly. The mean ranks of participants' scores were 4.20 of 6 on faculty issues, 4.36 of 6 for special education issues, 5.37 of 6 on student issues, and 5.51 of 6 on topics of tort liability.

Table 3

Descriptive Statistics for Scores in School Law $(n=257)$

\begin{tabular}{llr}
\hline Variable & Mean & SD \\
\hline Church and State & 4.14 & 1.064 \\
Faculty Issues & 4.20 & .899 \\
Special Education & 4.36 & 0.970 \\
Student Issues & 5.37 & 0.810 \\
Tort Liability & 5.51 & 0.619 \\
\hline
\end{tabular}

In order to determine if there were demographic group differences in scores in school law areas, nonparametric tests were conducted individually for each demographic variable. Nonparametric statistics were chosen because the response scores were ordinal, with each respondent's score for a given area (e.g., knowledge of church and state) being the number of questions answered correctly. Each of these scores could only be $0,1,2$, or 3. The Kruskal-Wallis test was conducted for those demographic variables with three or more levels. The Mann-Whitney U was used to determine whether or not the mean of two groups were different from each other in cases if the Kruskal-Wallis test was significant and if the independent variable had only two levels. The seven demographic groups studied were: type of school, years spent as a teacher, years spent as a principal, type of program, type of course, number of courses, and method used to teach courses. Years spent as teacher and years spent as principal were respectively collapsed into quartiles. For years as teacher, the following quartiles were obtained: under 10 years, first quartile; 10-14 years, second quartile; 15-21 years, third quartile; over 21 years, fourth quartile. For years of experience as principal, the following quartiles were 
obtained: under 5 years, first quartile; 5-8 years, second quartile; 9-17 years, third quartile; over 17 years, fourth quartile.

\section{Quantitative Research Questions}

Research question one. Do elementary school principals, middle school principals, and high school principals have different scores in knowledge of school law and application of school law in the five areas tested: separation of church and state, faculty issues, special education, student issues, and tort liability?

$\mathrm{H}_{\mathrm{o}}$ : There is no statistically significant difference when comparing scores of principals of elementary, middle, and high schools on their knowledge of school law and application of school law in the five areas tested: separation of church and state, faculty issues, special education, student issues, and tort liability.

$\mathrm{H}_{0}$ : all group mean ranks are equal

$\mathrm{H}_{\mathrm{a}}$ : Elementary school principals, middle school principals, and high school principals have different scores in knowledge of school law and application of school law in the five areas tested: separation of church and state, faculty issues, special education, student issues, and tort liability.

$\mathrm{H}_{\mathrm{a}}$ : not all the group mean ranks are equal.

The results of the nonparametric tests for the type of school revealed no statistically significant differences in scores of knowledge level questions by principals of elementary, middle, or high school. However, scores on application scenarios in the area of student issues was significant when analyzed with the Kruskal-Wallis test $(p=.044)$. Subsequently, the Mann-Whitney U test was used to compare scores of the three sets of two independent variables: elementary and middle, middle and high, and elementary and 
high. Only one set of paired scores showed a significant difference. High school principals scored significantly higher than elementary principals on questions involving student issues $(p=.014)$. No other findings were significant for this independent variable.

Research question two. Is there a difference in the knowledge and application of school law scores of principals in the five areas tested: separation of church and state, faculty issues, special education, student issues, and tort liability, and the number of years the principals worked as a teacher when compared by quartiles of experience?

$\mathrm{H}_{\mathrm{o}}$ : There is no statistically significant difference when comparing knowledge and application scores of principals and the quartiles of number of years principals have worked as a teacher in the five areas tested: separation of church and state, faculty issues, special education, student issues, and tort liability.

$\mathrm{H}_{\mathrm{o}}$ : all group mean ranks are equal

$\mathrm{H}_{\mathrm{a}}$ : There is a statistically significant difference when comparing knowledge and application scores of principals and the quartiles of number of years principals have worked as a teacher in the five areas tested: separation of church and state, faculty issues, special education, student issues, and tort liability.

$\mathrm{H}_{\mathrm{a}}$ : not all the group mean ranks are equal

Nonparametric tests for the quartiles of teaching experience were conducted. Respondents provided a self-report for number of years worked as a teacher. Years spent teaching were collapsed into quartiles with the following quartiles obtained: under 10 years, first quartile; 10-14 years, second quartile; 15-21 years, third quartile; over 21 years, fourth quartile. 
The Kruskal-Wallis test showed significant differences in scores on the knowledge questions about separation of church and state. Mean ranks in knowledge scores were significant at the $p=.007$ level. Follow-up Mann-Whitney U tests comparing quartile scores showed one significant difference in knowledge of school law. Principals in the first quartile, with under 10 years of teaching, scored higher on knowledge level questions involving the separation of church and state than principals in the third $(p=.011)$ and fourth $(p=.001)$ quartiles, with 15-21 years and over 21 years of teaching, respectively. No other findings were significant for this independent variable.

Research question three. Is there a difference in the knowledge and application of school law scores of principals in the five areas tested: separation of church and state, faculty issues, special education, student issues, and tort liability, and the number of years of experience as a principal?

$\mathrm{H}_{0}$ : There is no statistically significant difference when comparing knowledge and application scores of principals and the quartiles of number of years principals have worked as a principal in the five areas tested: separation of church and state, faculty issues, special education, student issues, and tort liability.

$\mathrm{H}_{\mathrm{o}}$ : all group mean ranks are equal

$\mathrm{H}_{\mathrm{a}}$ : There is a statistically significant difference when comparing knowledge and application scores of principals and the quartiles of number of years principals have worked as a principal in the five areas tested: separation of church and state, faculty issues, special education, student issues, and tort liability.

$\mathrm{H}_{\mathrm{a}}$ : not all the group mean ranks are equal 
Respondents were asked to write the number of years spent as a principal and the responses were collapsed into quartiles as follows: under 5 years, first quartile; 5-8 years, second quartile; 9-17 years; third quartile, over 17 years, fourth quartile. The KruskalWallis test only revealed a statistically significant difference knowledge of church-state with $p=.026$.

Using the Mann-Whitney U test, principals in the third quartile, with 9-17 years experience, scored significantly higher on knowledge of church and state issues than principals in the second quartile, with 5-8 years experience with $p=.004$.

Years as principal also resulted in a significant difference among quartiles in application of school law to church state issues. The Kruskal-Wallis test was significant at $p=.046$ on application of school law to church and state issues. The MannWhitney $U$ revealed that principals in the second quartile with 5-8 years experience scored significantly lower on church state issues than principals in the third and fourth quartiles who had 9-17 years and greater than 17 years experience $(p=.016$ and $p=.019$, respectively). No other findings were significant for this independent variable.

Research question four. Do principals who took school law courses in a master's program in educational leadership (public school) have different scores than principals who took school law courses in an 18-hour certificate program in public school administration and principals who took their school law coursework elsewhere, in knowledge of school law and application of school law in the five areas tested: separation of church and state, faculty issues, special education, student issues, and tort liability? $\mathrm{H}_{\mathrm{o}}$ : There is no statistically significant difference when comparing the type of program where principals took school law coursework and their knowledge of school law and 
application of school law in the five areas tested: separation of church and state, faculty issues, special education, student issues, and tort liability.

$\mathrm{H}_{\mathrm{o}}$ : all group mean ranks are equal

$\mathrm{H}_{\mathrm{a}}$ : There is a statistically significant difference when comparing the type of program principals took school law coursework and their knowledge of school law and application of school law in the five areas tested: separation of church and state, faculty issues, special education, student issues, and tort liability.

$\mathrm{H}_{\mathrm{a}}$ : not all the group mean ranks are equal

The results of the nonparametric tests for principals who took their school law courses in a master's program in educational leadership (public school), principals who took their school law courses in an 18-hour certificate program in public school administration, and principals who took their school law coursework elsewhere, were not significant in knowledge of school law in the five areas tested.

However, the ability to apply knowledge in the area of tort liability was found to be significantly different. Results of the Kruskal-Wallis test were significant at $p=.027$. The follow-up Mann-Whitney U showed a significant difference of $p=.009$ as principals who completed an 18-hour certificate program scored significantly higher than counterparts who completed a master's program in educational leadership. No other findings were significant for this independent variable.

Research question five. Do principals who took school law courses covering multiple topics in school law have different scores than principals who took school law courses dedicated purely to school law in knowledge of school law and application of 
school law in the five areas tested: separation of church and state, faculty issues, special education, student issues, and tort liability?

$\mathrm{H}_{\mathrm{o}}$ : There is no statistically significant difference when comparing the type of course taken in school law and their knowledge of school law and application of school law in the five areas tested: separation of church and state, faculty issues, special education, student issues, and tort liability.

$\mathrm{H}_{\mathrm{o}}$ : group mean ranks are equal

$\mathrm{H}_{\mathrm{a}}$ : Principals who took school law courses covering multiple topics in school law have different scores than principals who took school law courses dedicated purely to school law in knowledge of school law and application of school law in the five areas tested: separation of church and state, faculty issues, special education, student issues, and tort liability.

$\mathrm{H}_{\mathrm{a}}$ : group mean ranks are not equal

The results of the nonparametric Mann-Whitney U test comparing scores of principals who took coursework covering multiple topics in school law and principals who took coursework dedicated only to school law did not reveal any significant differences. The results supported the null hypothesis. No findings were significant for this independent variable.

Research question six. Do principals who have taken variously one course, two courses, or three courses in school law have different scores in knowledge of school law and application of school law in the five areas tested: separation of church and state, faculty issues, special education, student issues, and tort liability? 
$\mathrm{H}_{\mathrm{o}}$ : There is no statistically significant difference when comparing the number of courses taken in school law and their knowledge of school law and application of school law in the five areas tested: separation of church and state, faculty issues, special education, student issues, and tort liability.

$\mathrm{H}_{\mathrm{o}}$ : all group mean ranks are equal

$\mathrm{H}_{\mathrm{a}}$ : There is a statistically significant difference when comparing the number of courses taken in school law and principals’ knowledge of school law and application of school law in the five areas tested: separation of church and state, faculty issues, special education, student issues, and tort liability.

$\mathrm{H}_{\mathrm{a}}$ : not all the group mean ranks are equal

Results of the Kruskal-Wallis test for knowledge level scores were significant at $p=.042$. Subsequent analysis using the Mann-Whitney $\mathrm{U}$ test showed one significant difference. Principals who took only one course in school law scored higher in knowledge questions involving separation of church and state than principals who took two school law courses ( $p=.013$ ). There was no statistically significant difference in the ability of those principals to answer application level questions. No other findings were significant for this independent variable.

Research question seven. Do principals whose school law courses were taught using fact-based knowledge have different scores than principals whose school law courses were taught using case-based application in knowledge of school law and application of school law in the five areas tested: separation of church and state, faculty issues, special education, student issues, and tort liability? 
$\mathrm{H}_{\mathrm{o}}$ : There is no statistically significant difference when comparing the scores of principals with methods used to teach school law courses taken in school law and their knowledge of school law and application of school law in the five areas tested: separation of church and state, faculty issues, special education, student issues, and tort liability.

$\mathrm{H}_{\mathrm{o}}$ : group mean ranks are equal

$\mathrm{H}_{\mathrm{a}}$ : There is a statistically significant difference when comparing the scores of principals with methods used to teach school law courses taken in school law and their knowledge of school law and application of school law in the five areas tested: separation of church and state, faculty issues, special education, student issues, and tort liability.

$\mathrm{H}_{\mathrm{a}}$ : group mean ranks are not equal

The results of the nonparametric Mann-Whitney U test to compare knowledge and application scores for principals whose school law courses were taught using casebased application and principals whose school law courses were taught using fact-based knowledge did not reveal any significant differences. The results supported the null hypothesis. No findings were significant for this independent variable.

\section{Perceptions About School Law Preparation and Professional Development}

\section{Qualitative Questions}

Open-ended questions provided a forum for principals to share thoughts about essential elements for school law coursework and suggestions for professional development. Questions were asked regarding likes/dislikes of teaching style(s) experienced in school law courses in university preparation, areas of school law where 
further coursework is recommended, and areas of school law most beneficial for principals’ professional development.

Question one. Explain what you liked/disliked about the teaching style(s) used in the school law course(s) you took in your university principal preparation program.

Although only 257 of the respondents completed enough items needed for quantitative analysis of the research questions, more than half of the total respondents (184 of 322) answered question one. Many responses were either knowledge (20) or application (91) coded by identifying keywords and phrases in the responses. The majority of respondents constructed statements to support the use of case-based applications in school law coursework. Representative comments include:

- The professor took actual cases and created scenarios that checked our understanding of the law.

- Case study with group work - teacher gives right response

- I liked looking at cases and explanations of the judges’ decisions.

- In the classes that I had, the format was read the research, respond to a posted discussion question, and discuss with the class and instructor to develop an understanding of the law. I really liked this format and I feel it gave me a good understanding of school law.

- I enjoyed the stories that went along with the law. It's always interesting to read past cases and then to put that information into scenarios.

- The instructor was a past high school principal and used real life examples. 
- Enjoyed that [the] professor teaching course had been a school superintendent himself and could explain how theory gets put into practice.

- I liked the school law case method used by my professor.

- I liked the thoroughness and the many examples from the real world used to clarify the law. 'Emphasis on personnel issues were particularly important since they impact most teachers and educators.

- I liked working with case studies; it helped in preparation for real life.

- My school law course concentrated on scenarios similar to the ones presented in this survey.

Survey participants whose responses indicated coursework was primarily factbased indicated more value might have been achieved with emphasis on application. A participant wrote as a dislike, “not having enough specific case law examples.” Another noted the school law coursework was "straight lecture - memorization of court cases.” A principal stated, “I disliked the lecture-type style used and would prefer a more hands-on approach such as working with scenarios.” Only one participant indicated a preference for memorization of laws writing, "I did like reading the cases and understanding the nuances, but learning a rule of law is easier.”

Principals also reported having coursework that included both knowledge level and application of school law. One wrote, “The course included both lecture and case study. I felt it was effective” and another, "Liked both fact based teaching and situational teaching.” 
A few principals indicated they could barely remember anything about their coursework instruction. Participants offered positive comments regarding the benefit of classes sometimes taught by lawyers, former principals, and superintendents. Some principals appeared to advocate for greater focus on localized legal issues, commenting “Not enough study of actual West Virginia statutes.”

Many principals expressed concerns about school law coursework length including the time needed to adequately teach school law:

- Not enough time allotted for school law course. This could be a six-hour course.

- Course was interesting but needed more courses as it is a broad subject.

- Not enough time to go as deeply as needed.

- I think it is difficult to teach the amount of school law knowledge needed in only one class.

Some other principals made other general comments about school law coursework:

- Teaching style was not an issue. The dearth of instruction in all aspects of school law was and continues to be a great concern. Prevailing societal norms encouraging litigation begs that more instruction be provided aspiring teachers and administrators.

- I loved my classes on law best—practical

- There is never going to be enough time available to discuss all the subtleties of school law. That is why ongoing professional development is so vital. 
Question two. What area(s) of school law do you recommend for more university preparation in school law coursework?

More than 56\% of the principals (181 of 322) responded to this question. The most frequent response recommending more university preparation in school law coursework was in the area of special education. Eighty-two of the 181 principals (45\%) who answered this question indicated a need for coursework in special education law as a part of principal preparation. One principal noted, "I would recommend more classes on Special Education and the law. As a principal, I spend the majority of my time dealing with Special Education issues.” The 82 responses were summed up by another survey participant who wrote, “SPECIAL EDUCATION, SPECIAL EDUCATION, SPECIAL EDUCATION.”

Participants were able to recommend more than one in response to question two; therefore, the response numbers to this question exceed the number of respondents. Principals indicated a need for more university preparation in school law regarding student issues (39), faculty issues (35), tort liability (10) and separation of church and state (6). Specific student issues included search and seizure (3), harassment (3), and bullying (2). One principal wrote about a need for legal preparation to include "sexting," an area that could be included as a student issue or in the emerging category of school law related to technology. The area of school finance was also included (7). One principal provided a thoughtful response to the question about recommendations for more university preparation in school law:

In WV, I would recommend more time spent on teacher issues and principal authority as related to instructional delivery as well as overall management 
guidelines. It seems to me that teachers are entrenched in their ways of doing things and principals need to have a clear understanding of their authority . . . i.e., can you require teachers to stay after school for WESTEST Trainings and faculty meetings, what types of behaviors are insubordinate to the principal and can be dealt with clearly under policy 5310.

Responses to question two sometimes went beyond the stated question. Principals freely constructed comments including the following observations and advice:

- I do not think it should be limited to university preparation, the laws are continually changing therefore there should be on-going staff development to keep abreast of cases and the changes in law as well as the extenuating circumstances that go along with each of the cases.

- Special Ed. law changes so much that there should be annual reviews of it. Personnel law should also be renewed on a regular basis.

- Special Education is ever changing - must be updated to meet these changes more often.

- Special education law has the most potential for trouble for administrators.

- School law should be a course of its own not part of another course. There should be practical use of the cases for interpretation.

- There needs to be more taught about the financial aspect of school law. I got very little of that.

- $\quad$ Three courses along the line of what the one course was - but expanded. Everyone wants to sue. 
- All areas of school law should be equally well covered. It is more important for prospective administrators to know where to go to find answers than to try to remember everything a lawyer would remember.

- Any classes you are offered take them, the laws are constantly changing and you need to keep updated on everything.

Question Three. What areas of school law would you recommend for professional development in order to have a better background or better understanding?

Most of the principals (174 of 322) responding to the Williams School Law Survey completed question three. Again, special education garnered the highest response (62), with faculty issues (34) and student issues (33) as other important areas. Tort liability was mentioned seven times and separation of church and state appeared four times.

Responses also included explicit recommendations for more information regarding legal aspects of school finance (11). Principals noted some general issues including concerns about First Amendment rights, interaction with law enforcement, and safety. Specifically, principals requested continuing education programs for updates on special education, personnel law, Family Educational Rights and Privacy Act (FERPA), parental rights, search and seizure, tort liability, and discipline/grievance procedures. The principals’ case for regular updates on school laws was compelling:

- This would have to be consistent staff development. Laws change on a constant basis!

- Yearly updates of new cases affecting school operations.

- Continued updates on changes in the laws that affect the schools

- Continual updates on new laws - especially student issues 
- 'Workshops that focus on current law. Look at court cases where school boards and school administrators have prevailed or not prevailed.

- Case study as related to instruction, curriculum and classroom management in $\mathrm{WV}$; it would be nice to see improvement plans as related to these issues and gain a better understanding of how to improve teachers that should not be in education, but have 20 years of experience.

- Advocacy - how to get the law changed when it is impractical and unworkable - instead of having to work the unworkable.

- I believe finance is one of the most important areas of law that changes most frequently and in order to have a better understanding and be kept up to date more professional development

- We need more attention to school law for principals. When offering such courses, principals could come prepared with questions regarding their current situations.

- $\quad$ updates similar to those provided to me by NASSP on a regular basis they discuss current legal interpretations

- revisiting things like the speeches and prayers given by students; the idea surrounding checking the yearbook, etc.

- Every year we have an administrators' update CE conducted by a school law attorney -- I think this is very good -- helps us to stay tuned to new cases and decisions

- Annual updates as laws change 
- All of the areas are needed for an understanding for assist in making the best-informed decision.

- SpEd, Free Speech, and Interaction with law enforcement

- $\quad$ Special education law and personnel law are two huge areas of consideration.

- Always IDEA! [Individuals with Disabilities Education Act]

Question four. Check any areas of school law you feel would be most beneficial for principals' professional development.

A checklist was provided so principals who may not have taken time to construct responses to the first three questions could still indicate which areas of school law would be most beneficial for their professional development. Options for selection included the five areas of school law in the research study: church-state issues, faculty issues, special education, student issues, and tort liability and a checkbox for other (fill-in below). Eighty percent (258 of 322) of the survey participants opted to check areas for principals' professional development with response numbers presented in Figure 2. 


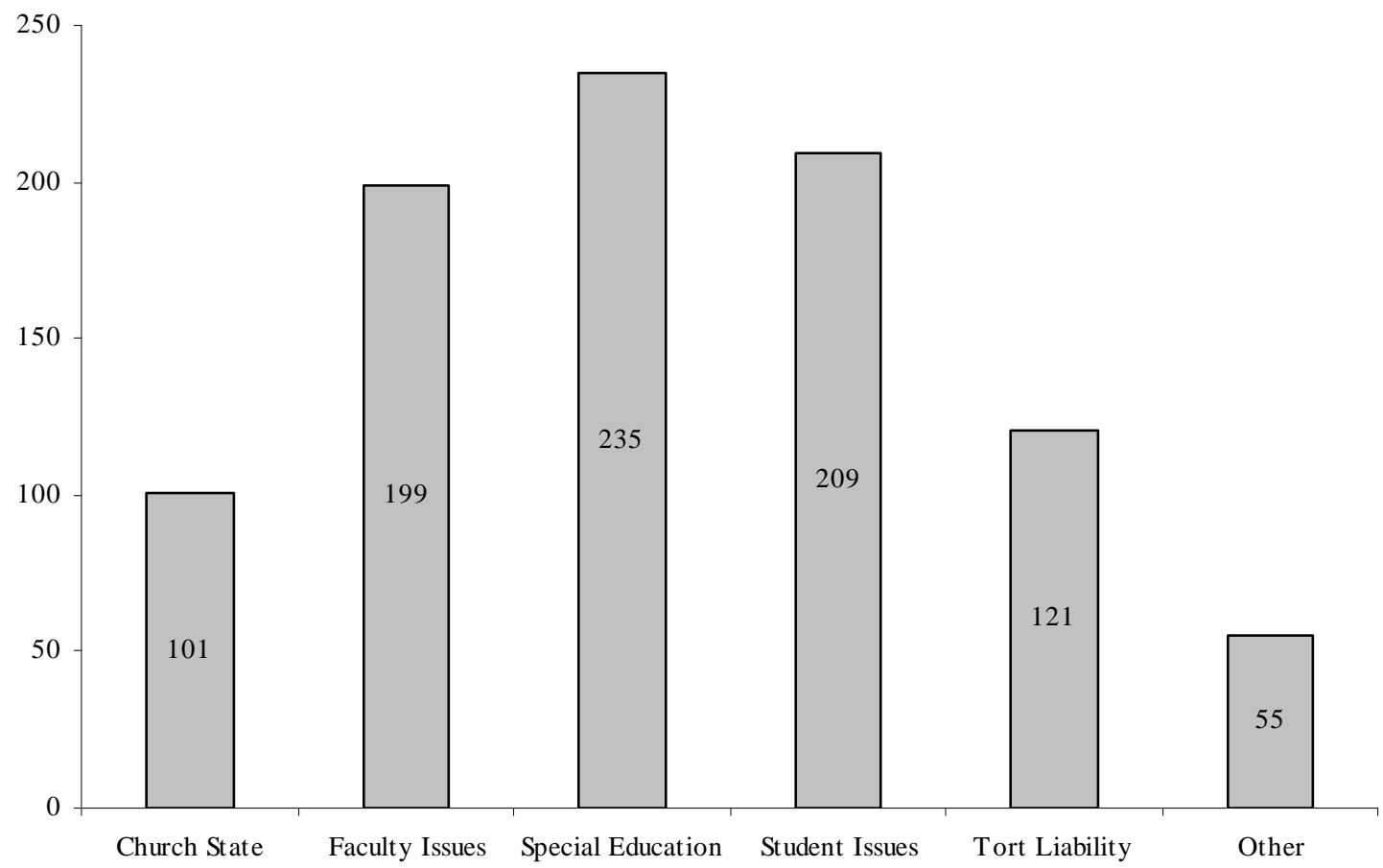

Figure 2. Principals’ suggestions for areas of school law most beneficial for professional development

Principals indicated a clear desire to have access to professional development in the five areas of law included in the research survey. Fifty-five respondents checked the last choice, other, and elaborated with a subsequent constructed response entry.

Question five. Other areas of school law suggested for professional development.

Principals constructed responses in this category as follow up to question four: areas of school law most beneficial for principals’ professional development. Some constructed responses belonged in one of the five areas already listed. For example, 18 of 55 constructed responses listed were related to faculty issues:

- sports which includes hiring practices of non teachers as coaches

- teacher rights and responsibilities, Administrators’ rights, etc 
- teacher's rights

- personnel law

- personnel

- grievance board decisions

- loss time accidents

- faculty issues

- rights of teachers

- $\quad$ service personnel laws

- faculty protection from reprisal

- personnel law- including service personnel.

- $\quad$ personnel Law (Professional and Service)

- hirings

- teacher's rights and the grievance process

- 504 \& service employees issues

- Teacher/Professional Issues

- specifically - Teacher Authority Sec. 18A-5-1 of the WV Code

Constructed responses related to student issues included:

- bullying

- discipline

- FERPA and custody issues

- parental issues 
Principals also mentioned two issues seemingly related to special education.

Responses of "due process" and "rights to assume the education of the student over the parent,” may refer to special education issues including: free, appropriate public education (FAPE); least restrictive environment (LRE); or related services.

Two other areas of concern seemed to fit the category of tort liability: building and communities (example: the use of playground facilities after hours and the school's liability); and liability for before/after school activities.

Two areas of school law not included in the survey were also noted: finance and technology. Ten principals wanted professional development to address finance issues. Only two respondents listed technology issues. One principal wrote "technology abuse by students," and the other cited “cell phones, sexting, texting, Internet, MySpace, Facebook, etc.” as an area of need for professional development.

\section{Summary of Findings}

The Williams School Law Survey provided data regarding differences in knowledge and application of school laws across various demographic factors among principals and principal perceptions about school law preparation and professional development. Quantitative data was analyzed from online surveys gathered from completed surveys of 257 principals in West Virginia. Nonparametric tests were conducted to determine group differences in school law scores across demographic groups. Differences noted using the Kruskal-Wallis test were subsequently tested using the Mann-Whitney U test.

Knowledge level findings. Tests of demographic factors that showed significant differences in knowledge of school law scores included: (a) years of teaching experience 
and knowledge of issues of separation of church and state; (b) years of principal experience and school law scores for knowledge of issues of separation of church and state; and (c) number of law courses taken and knowledge of separation of church and state.

The first significant finding when comparing knowledge level scores of respondents was a difference in years of teaching experience. Principals with less than ten years of teaching experience (first quartile), scored higher on questions about churchstate, than principals with 15-21 years (third quartile) and over 21 years (fourth quartile) of teaching.

The second significant finding when comparing knowledge level scores of respondents was a difference in years of experience as a principal. A significant difference was found. Principals with 9-17 (third quartile) years of principal experience scored significantly higher on knowledge of church-state issues than principals with 5-8 years (second quartile).

The third finding with a significant difference was the number of school law courses taken. Principals who reported taking only one course in school law scored higher than principals who reported taking two school law courses in knowledge questions involving separation of church and state.

Application level findings. Tests of demographic factors that showed significant differences in application of school law scores included: (a) type of school where principals worked compared with application of student issues; (b) quartiles of experience as a principal and school law scores for application of issues of separation of 
church and state; and (c) type of program where school law coursework was taken and application of tort liability.

The first application level finding, scores grouped by the type of school where principals worked - elementary, middle, or high school - were paired for analysis. Only one set of paired scores showed a significant difference, as high school principals scored significantly higher than elementary principals on questions involving application scenarios of student issues.

The second application level finding involved the number of years as principal. A significant difference was found among quartiles in application of school law to church state issues. Data revealed principals in the second quartile, with 5-8 years experience, scored significantly lower on church state issues than principals in the third and fourth quartiles who had 9-17 years and greater than 17 years of experience.

The last application level finding was between the types of programs - eighteenhour certificate and masters level - where school law coursework was taken. A significant difference was found. Principals who took an 18-hour program in public school administration had higher scores in school law on tort liability than principals certified through a masters program.

\section{Principals’ perceptions about school law preparation and professional}

development. The majority of principals who participated in the survey constructed responses to questions about what they liked/disliked about school law courses taken in principal preparation programs, areas of school law recommended for more university preparation, and areas of school law recommend for professional development. 
The majority of respondents constructed statements to indicate they preferred the use of a case-based approach in their school law coursework. Survey participants whose responses reported that their coursework was primarily fact-based indicated a further need for an emphasis on application level activities in coursework. Some respondents indicated a preference for us of both factual and application information in their school law coursework. Participants who did not receive training in case-based school law expressed a need for case-based training.

The area of school law with the most recommendations for more university preparation was special education law, recommended more than twice as often as any other category. Principals indicated a need for more university preparation in school law regarding student issues, faculty issues, tort liability and separation of church and state. Specific student issues included search and seizure, harassment and bullying. School finance was an area some principals considered important to their preparation. A need to include technology issues related to "sexting” was also noted.

Principals made recommendations of areas for professional development in order to have a better background or a better understanding of school law, most notably special education. Faculty issues and student issues appeared frequently. The need for professional development related to tort liability and church-state were less concerning with only a few mentions. As noted in recommendations for more university preparation, school finance law was an area some listed as needed for professional development. 


\section{Chapter Five}

\section{Summary, Conclusions and Recommendations}

This chapter has three sections. The first section reviews the study purpose and methodology and provides a summary of the findings. The second section presents the research findings and explores the relationship to the theoretical framework. The last section presents recommendations for the design of principal preparation programs, recommendations for professional development in school law for practicing principals, and suggestions for further research.

\section{Summary}

Purpose and methodology. The purpose of this research study was to determine if a relationship existed among principals’ ability to accurately answer school law questions given application scenarios and fact-based statements as compared with seven selected independent variables: programmatic level of the school; experience as a teacher; experience as an administrator; type of credentialing program; type of school law course taken; number of school law courses; and reported pedagogical construct of course delivery. The study also gathered information regarding principals’ perceptions of their own school law preparation, recommendations for university preparation programs and recommendations for professional development.

A four-part web-based survey questionnaire was used to gather data. Part one included self-report for seven independent variables. Part two presented scenarios representing five areas of school law, allowing principals to apply knowledge of school law, given a choice of two responses. Part three presented fifteen statements representing the same five areas of school law, allowing principals to demonstrate recall of factual 
knowledge, given a choice of true or false. Part four included four items for constructed responses, allowing principals to explain likes/dislikes of university level school law coursework, recommendations for university preparation, professional development, and a checklist for areas of school law that would best benefit principals’ professional development.

The survey study was sent electronically to West Virginia’s 704 principals. A quantitative causal comparative research design was used. Data entry and analysis was accomplished using the Predictive Analytics Software (PASW) with subsequent appropriate analysis. Nonparametric tests were conducted to determine group differences in school law scores across demographic groups. When significant differences were found using the Kruskal-Wallis test. Subsequent testing used the Mann-Whitney U test.

\section{Research Findings}

Knowledge level research findings. Data analysis for knowledge level questions had findings in the area of separation of church and state. Principals with less than ten years teaching experience, the first quartile, scored higher on questions about church and state than principals in the third and fourth quartiles with 15-21 years and over 21 years of teaching respectively. Principals with 9-17 years experience scored significantly higher on knowledge church state issues than principals with 5-8 years as principal. Principals who reported taking only one course in school law scored higher than principals who reported taking two school law courses in knowledge questions involving separation of church and state.

Application level research findings Data analysis for application level questions showed significant differences in ability to apply school law to student issues, church and 
state, and tort liability. High school principals scored significantly higher than elementary principals on questions involving application scenarios of student issues. Principals with more than nine years of experience scored higher than principals with 5-8 years on church state issues. Principals who took school law coursework in an 18-hour administrative certificate had higher scores for scenarios involving tort liability than principals certified through a masters program.

\section{Relationship to Theory}

This research study involved the three domains of leadership described in The Building Blocks for Preparing Good Educational Leaders in Troubled Times by Chapman et al. (2005). That model puts forth a theoretical framework for developing educational leadership preparation programs. The framework of cognition, pedagogy and leadership was integral in this study design. The model was adapted with educational leadership students replaced by current educational leaders, i.e., West Virginia principals.

The survey instrument assessed two levels of cognition - knowledge and application - and the interrelationship of cognition to pedagogy as it explored the relationship between knowledge and application of school law with independent variables. Findings showed that principals reported use of case-based scenarios in coursework more often than fact-based. Preferences for learning about school law were explicit in support of the use of application as appropriate for university preparation programs.

The survey also examined the type of administrative certificate program attended by participants and found that in an important area of school law, tort liability, principals 
who had school law coursework in an 18-hour certificate program, outperformed principals who received training in a master's program.

The elements of cognition, pedagogy and leadership are intertwined as principals’ knowledge and application of school law were demonstrated by answers on the school law survey. West Virginia principals who completed survey items scored well overall, with the mean score of 4.14 in on a scale of 0-6 (69\%) to a high of 5.15 (86\%), evidence that many principals have a working knowledge and ability to apply school law, an indicator, perhaps, of effective leadership.

\section{Recommendations}

Research results from this study, while not definitive with regard to all of the variables studied, yields some salient information of importance to stakeholders in three distinct areas. First, results of the study may inform higher education policy and procedure regarding effectiveness of administrative personnel preparation programs as demonstrated by principal's knowledge and application of school law. It is important to note principals who took school law coursework in 18-hour certificate programs scored as well or better on both knowledge and application of school law questions as principals who took coursework in a master's in educational leadership. Principals who attended an 18-hour certificate program scored significantly higher on scenario items than colleagues who attained a master’s degree in administration.

Professional preparation for principals should continue to include the option for teachers who have a master's degree in another area be allowed to complete a certificate program in order to obtain administrative credentials as a principal. Given the opportunity to make recommendations for university preparation in school law 
coursework, an overwhelming majority cited a need for special education law. Many also recommend the addition of more school law coursework and a pedagogical emphasis on application scenarios over a fact-based approach.

Second, data concerning specific areas of principal's knowledge of school law may be used to plan professional development for public school principals. Principals appear to have a gap in knowledge of some church and state issues. Areas for professional development clearly requested by principals included the five areas of school law included in the study - church-state, faculty issues, special education, staff issues, and tort liability - with the addition of school finance law. A few principals expressed a need for more information about student use of electronic media and technology.

Third, current principals need to have ongoing opportunities to maintain skills and learn about changes in school law by participate in professional development. Some expressed a need for regular updates on school law, especially in special education. The availability of data-driven professional development related to specific areas of school law may need to be ongoing as legal issues are increasing complex. In order to conserve valuable resources, it is recommended that online and webinar distance conferences be made available as options for professional development session on school law.

This research addressed West Virginia principals’ knowledge and application of school law and tangentially provided information about higher education and preparation of principals, preferred pedagogical construct of school law courses, and directions for professional development. It is recommended that findings be shared with the communities of leaders in higher education and professional development in West 
Virginia. Further, the study should be adapted and replicated in other states. Issues in school law are quickly changing. Emerging issues, including an increased concern with student issues of bullying and use of technology, should be expanded and addressed in future research.

This study also underscores the importance of surveying public school principals and other stakeholders about their needs and preferences regarding recommendations for professional preparation and topics for professional development. Meaningful follow up of surveys should result in improved principal preparation programs and provide timely and focused professional development for practicing principals. In particular, the expressed desire of principals to have more preparation and ongoing professional development in special education law is a finding that should be addressed in order to provide better education and services to students and more thorough and efficient school leadership. 


\section{References}

Alexander, K., \& Alexander, M. D. (2005). American public school law (6th ed.). Belmont, CA: Thomson-West.

Anderson, L. W. \& Krathwohl, D. R. Eds. (2001). A taxonomy for learning, teaching, and assessing: A revision of Bloom's Taxonomy of Educational Objectives. New York: Longman.

Bloom, B. J., Engelhart, M. D., Furst, E. J., Hill, W. H., \& Krathwohl, D. R. (1956). Taxonomy of educational objectives: The classification of educational goals. Handbook 1, Cognitive domain. New York: David McKay.

Brabrand, S. S. (2003). Virginia principals and school law (Doctoral dissertation, Virginia Polytechnic Institute and State University). Retrieved from http://scholar.lib.vt.edu/theses/available/etd-05052003155102/unrestricted/ssb1final.pdf

Bravenec, D. L. (1988). A critical needs survey of Texas elementary and secondary school principals regarding administrator preparation and administration of special education programs. Dissertation Abstracts International, 59(04), 1120A. (UMI No. 9830373)

Brown, N., Rubenstein, H., \& Seufer, H. (1999). School law issues in West Virginia. Eu Claire, WI National Business Institute.

Calabrese, R. L. (2002). The leadership assignment: Creating change. Boston: Allyn and Bacon. 
Caldwell, M. T. (1986). Virginia principals and school law (Doctoral dissertation, Virginia Polytechnic Institute and State University). Dissertation Abstracts International, 48, (05A), 1067.

Chambers, J. G., Harr, J. J., and Dhanani, A. (2003). What are we spending on procedural safeguards in special education, 1999-2000? : American Institutes for Research.

Chapman, P. E., Parks, J. D., \& Walls, R. T. (2005). The building blocks for preparing good educational leaders in troubled times. National Forum of Applied Educational Research Journal, 19(1), 20-34.

Clark, T. R. (1990). Mississippi superintendents' and secondary educators' knowledge of school law as it relates to student rights in selected areas (Unpublished doctoral dissertation). The University of Southern Mississippi. Dissertation Abstracts International, 51, (10A), 3282.

Copenhaver, M. B. (2005). Survey of North Carolina principals' knowledge of special education law. (Doctoral dissertation, Purdue University). ProQuest DIA 982811981. Retrieved from http://docs.lib.purdue.edu/dissertations/AAI3185748/

Daley, E. K., Jr. (1993). An assessment of the knowledge of tort liability law, in the areas of duty and standard of care, by selected teachers and principals, in the specific areas of sexual misconduct between professional school employees and students (Unpublished doctoral dissertation). George Mason University, Fairfax, VA

Davis, S., Darling-Hammond, L., LaPointe, M., \& Meyerson, D. (2005). School leadership study: Developing successful principals: Stanford Educational Leadership Institute 
DeMitchell, T. A. (2006). Negligence: What principals need to know about avoiding liability. Blue Ridge Summit, PA: Rowan \& Littlefield Education.

DiPaola, M., \& Tschannen-Moran, M. (2001). Report on the 2001 principals study. Williamsburg: The College of William and Mary.

DiPaola, M., \& Walther-Thomas, C. (2003). Principals and special education: The critical role of school leaders (No. COPPSE Document No. IB-7). Gainesville, FL: University of Forida Center on Personnel Studies in Special Education.

Dowling-Sendor, B. (2006). How to live in harmony with the law. American School Board Journal.

Dunklee, D. R., \& Shoop, R. J. (2006). The principal's quick-reference guide to school law: Reducing liability, litigation, and other potential legal tangles (2nd ed.). Thousand Oaks: Corwin Press.

Elmore, R. F. (2000). Building a new structure for school leadership. Washington, DC: Albert Shankler Institute.

Essex, N. (2005). School law and the public schools: A practical guide for educational leaders (3rd ed.). Boston: Pearson.

Essex, N. (2006). A teacher's pocket guide to school law. Boston: Pearson.

Gordon, H. (1997). Legal knowledge of secondary school principals: Impact of selected variables. Journal of Research in Education, 7(1), 49-54.

Green, R. L. (2001). Practicing the art of leadership. Upper Saddle River, NJ: PrenticeHall.

Hardin, D. T. (1998). What do superintendents think about principalship preparation programs? Paper presented at the Southwest Educational Research Association. 
Hess, F. M. (2004). A license to lead? A new leadership agenda for America's schools Washington, DC: Progressive Policy Institute.

Hess, F. M., \& Kelly, A. P. (2005). Learning to lead? What gets taught in principal preparation programs (No. PEPG 05-02): American Enterprise Institute.

Hirth, M. A. (1988). Principals' knowledge of Public Law 94-142 and significant court litigation in the area of special education (Unpublished doctoral dissertation). Memphis State University.

Hogan, J. C. (1974). The schools, the courts, and the public interest. Lexington, MA: Lexington Books.

Hogan, J. C. (1985). The Schools, the courts, and the public interest (2nd ed.). Lexington: Lexington Books.

Interstate School Leaders Licensure Consortium (2008). Educational leadership policy standards: ISLLC 2008 [Electronic Version] from http://www.ccsso.org/publications/details.cfm?PublicationID=365.

Jones, E. A. (2002). Transforming the curriculum: Preparing students for a changing world. San Francisco: Jossey-Bass.

Kalafitis, N. E. (1999). Principals' knowledge of legal issues related to search and seizure issues in Virginia (Unpublished doctoral dissertation). Dissertation Abstracts International, 60 (06A), 1849. (UMI No. 9936664)

Kerrigan, J. (1987). A study of the perceptions of school administrators regarding educational law, legal policies and procedures.(Unpublished doctoral dissertation). University of Massachusetts, Amherst, MA

LaMorte, M. (2005). School law: Cases and concepts (8th ed.). Boston: Pearson. 
Lane, K. E., Connelly, M. J., Mead, J. F., Gooden, M. A., Eckes, S. (2008). The principal's legal handbook: LexisNexis Publishing.

Larry, K. B. (2006). Principal perceptions of the relationship between professional development designs and the qualities, proficiencies, and leadership skills required of West Virginia principals (Doctoral dissertation). Retrieved from ttp://www.marshall.edu/etd/descript.asp?ref=664

Lashway, L. (2003). Transforming principal preparation [Electronic Version]. ERIC Digest, 165. Retrieved 11/05/2004.

Levine, A. (2005). Educating school leaders. Washington, DC: The Education Schools Project.

Littleton, M., Higham, R., \& Styron, K. (2001 ). Analysis of legal knowledge of school officials in Texas. Paper presented at the Education Law Association.

Locke, L. F., Silverman, S. J., \& Spirduso, W. W. (1998). Reading and understanding research. Thousand Oaks, CA: Sage.

Magone, M. A. (2007). Education law priorities and need: A comparative analysis (Doctoral dissertation). Retrieved from http://etd.lib.umt.edu/theses/available/etd09262007-112630/unrestricted/umi-umt-1038.pdf

McEllistrem, S., Roth, J.A., D'Agostino, T., Brown, C.J. (Ed.). (2007). Students with disabilities and special education law (24 ed.). Malvern, PA: Center for Education and Employment Law.

Milstein, M. M. (1993). Changing the way we prepare educational leaders: The Danforth experience. Newbury Park, CA: Corwin Press. 
Murdkic, N. L., Gartin, B. C., \& Crabtree, T. (2007). Special education law (2nd ed.). Upper Saddle River, NJ: Prentice Hall.

Murphy, J. (1992). The landscape of leadership preparation: Reframing the education of school administrators. Newbury Park, CA: Corwin Press.

Murphy, J., Ed. (1993). Preparing tomorrow's school leaders: Alternative designs. University Park, MD: UCEA.

National Policy Board for Educational Administration (2002). Retrieved from http://faculty.winthrop.edu/martinmb/ELCC_Standards.pdf

Osburn, C. E. (1990). Principals' knowledge of South Dakota school law (Unpublished doctoral dissertation). Dissertation Abstracts International, 51 (06A), 1859.

Portin, B., Schneider, P., DeArmond, M., \& Gundlach, L. (2003). Making sense of leading schools: A study of the school principalship. Seattle, WA: Center on Reinventing Public Education.

Power, D. (2007). A study of selected Virginia principals' knowledge of special education law (Doctoral dissertation). Virginia Polytechnic Institute and State University Blacksburg, VA etd-01252007-110510

Reglin, G. L. (1992). Public school educators' knowledge of selected Supreme Court decisions affecting daily public school operations. Journal of Educational Administration 30(9), 26-31.

Schlosser, R. (2006). An analysis of principal interns' legal knowledge and legal instruction in principal preparation programs (Unpublished doctoral dissertation). Sam Houston State University, Huntsville, TX 
Schlosser, R., \& Littleton, M. (2006). Principal preparation programs - Are we teaching the law that they need to know? Paper presented at the Education Law Association Annual Meeting, Nassau, Bahamas.

Singletary, I. R. (1996). South Carolina superintendents' and secondary educators' knowledge of school law as it relates to selected areas of student rights. (Unpublished doctoral dissertation). South Carolina State University, Orangeburg, SC.

Slasinski-Griem, C. (1990). State control of education. The American Journal of Comparative Law, 38, Supplement, 473-490.

Southern Regional Education Board. (2006). Schools can't wait: Accelerating the redesign of university principal preparation programs. Atlanta: Southern Regional Education Board.

Stephens, M. B. (1983). A study of legal competencies of selected school principals in relation to school law training (Unpublished doctoral dissertation). George Washington University, Washington, DC

Wilmore, E. L. (2002). Principal leadership: Applying the new educational leadership constituent council (ELCC) standards. Thousand Oaks, CA: Corwin Press.

Witt, D. E. (2003). An examination of how educational administration programs prepare principals in special education issues (Unpublished doctoral dissertation). Retrieved from http://www.uc.edu/urbanleadership/abstract_pdf/witt_de.pdf Wright, P. W. D., \& Wright, P. D. (2005). Wrightslaw: IDEA 2004. Hartfield, VA: Harbor House Law Press. 
W. V. Department of Education. (2009). Master list of all schools. Retrieved January 28, 2009 from

http://wveis.k12.wv.us/nclb/pub/enroll/mapMLsch.cfm?sy=10\&county=99

W. V. Department of Education. (2010). Draft: Policy 5800 - Standards of professional practice for West Virginia superintendents, principals and teacher leaders. Retrieved from http://wvde.state.wv.us/policies/p5800_co.pdf.

W. V. Leadership Development and Support Collaborative. (2009). Draft principal leadership standards: WV Leadership development and support collaborative. Retrieved from http://sites.google.com/site/wvleadershipcollaborative/meeting11

Yell, M. L. (2006). The law and special education (2nd ed.). Upper Saddle River, NJ: Pearson Education.

Zirkel, P. A. (1994). Costly lack of accommodations [Electronic Version]. The Phi Delta Kappan,, 75, 652-653 from http://www.jstor.org/stable/20405191

Zirkel, P. A. (1997). The "Explosion" in education litigation: An update. [Electronic Version]. West's Education Law Reporter. Retrieved November 20, 2006. 
Appendices 


\section{Appendix A: Participant Letter}

\section{WestVirginiaUniversity}

College of Human Resources and Education

May 19, 2009

Dear West Virginia Principal:

You are being asked to participate in an on-line questionnaire that is the data collection instrument for a research study being conducted by Nancy Ross Williams for her doctoral program at West Virginia University. The survey research, "West Virginia Principals' Knowledge and Application of School Law," is being conducted as part of Nancy Ross Williams' doctoral dissertation in Educational Leadership Studies at West Virginia University under the supervision of doctoral committee chair, Interim Associate Dean of the School of Human Resources and Education, Dr. Paul E. Chapman.

The purpose of this study is to learn more about principals' knowledge and application of school law when compared with demographic variables. Your participation in this study is completely voluntary. You may refuse to participate. If you would like to have your name removed from this list, click to go to the link and enter your email to be taken off the list Remove my email

If you choose to participate, you may quit at any time or skip any question. All survey responses are anonymous. The survey and responses will be encrypted. The storage of the data will be electronic and no personally identifying information will be collected. West Virginia University's Institutional Review Board has acknowledged this study. Go to the survey now by clicking here: $\underline{\text { School Law Survey }}$

After completing the survey, you will have the opportunity to go to another web page to enter your email in order to receive a post-survey resource with information about correct survey responses, including references to all laws, case law, or codes, related to the school law issues on the survey. The post-survey resource will be sent at the conclusion of the study and will provide direct benefit to all principals who respond to the survey. This study will be of value as results are used to inform principal preparation programs and provide direction for staff development. Each survey, including yours, impacts the study as a whole. The overall response rate is very important to the findings in the study. Thank you in advance for taking your valuable time to participate. Please complete the survey before June 10,2009. If you have any questions, please contact me at 304-676-4667 or via email at nwillia7@mix.wvu.edu.

Sincerely,

Nancy Ross Williams

WVU Doctoral Candidate

\begin{tabular}{|c|c|}
\hline$=\quad$. & Educational Leadership Studies \\
\hline & 608 Allen Hall \\
\hline $3 \cdot 22$ & Morgantown, WV $26506 \cdot 6122$ \\
\hline
\end{tabular}




\section{Appendix B: Letter of Support from Dr. Paine}

\begin{tabular}{ll} 
West Virginia & $\begin{array}{l}\text { Dr. Steven L. Paine, State Superintendent of Schools } \\
\text { 1900 Kanawha Boulevard, East, Building } 6 \\
\text { Charleston, West Virginia 25305-0330 } \\
\text { Phone: 304-558-2681 } \\
\text { Fax: 304-558-0048 }\end{array}$ \\
\hline Department of Education &
\end{tabular}

May 7, 2009

Dear Principal,

This is a letter of support for Nancy Ross Williams, a doctoral candidate in Educational Leadership at West Virginia University, who is completing a research study under the supervision of Dr. Paul E. Chapman. I encourage you to participate in this research study by completing an online survey, "Williams School Law Survey," being sent to you by email this week. This important study will provide data about principals' knowledge of education law.

The web-based questionnaire will be used to gather information about principals' knowledge and application of school law, demographics of participating principals, designs of administrative programs attended by participants, the amount and type of school law preparation, type of credentialing programs, years in education and years in administration.

This study is significant in that it will provide data to support staff development for public school administrators, as well as inform higher education preparation programs. Additionally, as a participating principal, you may opt to receive a "Post-Survey Resource" document, reinforcing and enhancing your own knowledge of school law.

As you know, a high survey response rate is important to provide reliable data. Again, I encourage you to participate in this important research.

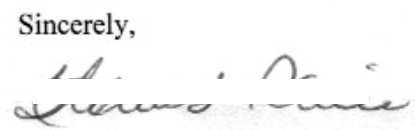

Steven L. Paine

State Superintendent of Schools

$\mathrm{SLP} / \mathrm{rh}$ 


\title{
Appendix C: IRB Acknowledgement
}

\section{WestVurginiaUniversity.}

Office of Research Compliance

\section{Expedited-IRB Protocol-Exemption}

\author{
To: Chapman, Paul \\ From: WWU Office of Research Compliance \\ Date: Wednesday, May 13, 2009 \\ Subject: Exemption Acknowledgement \\ Tracking \#: $\mathrm{H}-21707$ \\ Title: West Virginia Principals' Knowledge and Application of School Law
}

The above-referenced study was reviewed by the West Virginia University Institutional Review Board (IRB) and was granted exemption in accordance with 45 CFR 46.101(1 $6)$.

This protocol was reviewed using the following:

This research study was granted an exemption in accordance withEducational tests, survey procedures, interview procedures, or observation of public behavior [45 CFR 46.101(2)].

The following documents have been acknowledged for use in this study and are available in the BRAAN system:
Survey
Cover Letter

Thank you.

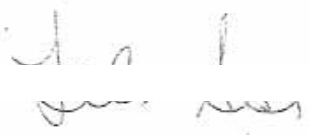

Board Designee: Ast, Lilo

Letter Sent By: Ast, Lilo, 5/13/2009 4:59 PM

Once you begin your human subject research, the following regulations apply:

1. Any modifications to the study protocol must be reviewed and acknowledged by the IRB prior to implementation.

2. You may not use a modified form until it has been acknowledged by the IRB. 
Appendix D: Williams School Law Survey

\section{Williams School Law Survey, Nancy Ross Williams}

Introduction

The Williams School Law Survey is an on-line questionnaire that is the data collection instrument for a study being conducted by Nancy Ross Williams for her Educational Leadership Studies doctoral program at West Virginia University.

It will take about ten minutes to complete the survey.

There are four quick parts:

1) demographic information

2) fifteen scenarios

3) fifteen true/false statements

4) reflection on school law preparation and staff development suggestions

Remember, all responses are anonymous.

You may skip any questions.

To request the post-survey school law resource, you need to go to the end of the survey and click DONE.

You will be directed to a separate survey link that is not connected in any way with your survey responses. 


\section{Survey Part 1: Demographic Information \\ Please check the appropriate response. \\ 1. I am principal of a school best described as \\ Elementary \\ Middle School \\ High School \\ Voc/Tech School}

Williams School Law Survey, Nancy Ross Williams

2. Enter the number of years you have worked as a teacher and Enter the number of years you have worked as a principal

number of years

teaching

number of years as

a principal or other

administrator

\section{Indicate the type of program where your school law coursework was taken}

18-hour certificate program in public school administration

Master's in Educational Leadership, Public School

School Law Coursework other than certificate or Master's including undergraduate or doctoral level

\section{Indicate the type of school law course you have taken}

3-hour course dedicated to school law only

3-hour course addressing multiple topics with school law (administrative skills/school law; law/finance/facilities; legal and policy issues)

\section{State the number of law courses you took}
One
Two
Three or more

6. The methods used to teach my school law course(s) were primarily
$\bigcirc$ fact-based knowledge
case-based application 


\section{Williams School Law Survey, Nancy Ross Williams} Survey Part 2 of 4

Read the scenario and select a response.

1. An honor roll student expected to be inducted into the school's honor society. However, the student was not among the students named in the announcement to participate in the induction meeting. The student's parents contacted the principal and stated that because of their FERPA rights, they had the right to review teacher ratings of their student as well as those of students admitted to the honor society. The parents threatened to get a lawyer and sue unless their request was met.

The principal must deny the parent request.

The principal must comply with the parent request.

2. A student was left alone in the assistant principal's office for a few moments and when the assistant principal returned, they had a brief conversation. The student then picked up his backpack and left to go to his locker and on to class. A short time after, the assistant principal discovered a bank envelope with ticket money was missing. The student had a record of thefts and was the only person in the office prior to the theft. Board policy does permit general searches and students are notified of this fact through the student code of conduct. The assistant principal

does not have cause to search the student's locker without a search warrant.

has cause to search the student's locker without a search warrent.

3. A Journalism class submitted its school newspaper for review by the principal before publishing. In the newspaper, two sections contained content that was sure to raise eyebrows. The first section included a story of three students (whose names had been changed) and their experiences with pregnancy. The second section was a story about how divorce had affected one of the students on campus. The stories presented only the students' points of view. The parents of the students in the stories were not allowed to defend any statements about them or their situation. Legally, the principal

cannot require the students to omit the sections because of the students' first amendment rights.

can remove the sections without infringing on the students' first amendment rights. 


\section{Williams School Law Survey, Nancy Ross Williams}

4. A second-grade child, who is profoundly deaf, attends a public school. The student's present level of educational performance is on grade level with grades of $A$ and $B$ in all subjects. At the Individualized Education Program (IEP) meeting, the child's parents, who are also deaf, request a full-time certified sign-language interpreter be included believing total communication is needed because their child is deaf. The principal and other members of the IEP team, except the parents, refuse to provide a sign-language interpreter, based on the student's performance at the current level of services.

The IEP team must consider and agree with the parents' request in order to comply with special education law.

The IEP team must consider and may refuse the parents' request and still be in compliance with special education law.

5. A third grade student reported to school on more than one occasion with suspicious bruises on the student's body and face. The student's teacher questioned the student about the bruises. After the latest incident, the teacher decided there was reasonable cause to suspect the child was being abused and decided something must be done. The teacher is legally obligated to

report the circumstances to the school administrator. The teacher or administrator must then make a report to the Department of Health and Human Resources not more than 48 hours after the teacher reasonably suspected abuse.

report the circumstances directly to the Department of Health and Human Resources within 48 hours without ever notifying a school administrator.

6. During the first day of school, a high school student refused to stand, say the Pledge of Allegiance, or salute the American flag after morning announcements. The teacher confronted the student who continued to refuse to participate in the pledge activity. The teacher then sent the student to the principal's office.

The principal cannot compel the student to participate or threaten disciplinary action.

The principal must explain to the student the school's expectation that all students participate in the pledge activity or face the threat of disciplinary action.

7. In planning the graduation ceremony, a student advisory committee submitted plans to the principal in advance for approval. Several students planned to lead the audience in an opening choral response prayer to be printed in the graduation program. Because the plan for the prayer was student initiated, the principal of the school approved the studentadvisory committee recommendation.

The principal acted correctly because the this is a free speech issue.

The principal should not have approved student-led prayer because of the establishment clause. 


\section{Williams School Law Survey, Nancy Ross Williams}

8. An IEP meeting was held with parents of a child with severe mental impairment and multiple disabilities. Services in place at the time of the meeting included a self-contained classroom in which all students were students with severe mental impairment and multiple disabilities. During the annual IEP meeting, the parents insisted that their child receive all special education services in regular education classes, which they considered the least restrictive environment. The principal responded by informing the parents that the school could not consider such a placement due to the severity of the impairments and maintained that the student's current placement was the most appropriate educational placement.

The IEP team must agree with the parents' request to include the student in regular education classes for all or part of the day in order to meet requirements for least restrictive environment.

The IEP team must consider the parents' request for change of placement based on the least restrictive environment along with other considerations, and then may refuse the parents' request.

9. A student-formed Christian club followed school-use procedures to request use of the high school campus before and after school for religious discussion and worship. The school had several other non-curricular clubs, including a ski group, and a service organization, that used the school during non-instructional time. The district

must allow the Christian club access to the school during non-instructional time.

may refuse to allow the club because it breaches the wall of separation between church and state.

10. A first-time principal was hired at a high school in August 2003. By the fall of 2005, complaints about one of the teachers had reached the principal. The complaints indicated that the science teacher had "befriended" one of his students, showed favoritism toward this young woman, and had begun a sexual relationship with her. In 2006, a student told the principal that she had witnessed the science teacher "molesting" one of the students in a private room of the school. The principal downplayed the incidents and did not attempt to warn or discipline the teacher. During the same year, a new superintendent was hired. The principal did not inform the superintendent of the situation.

The school district cannot be held liable because the principal had no proof of the accusation and did not inform the superintendent.

The school district may face liability for the principal's deliberate indifference to the situation. 


\section{Williams School Law Survey, Nancy Ross Williams}

11. A transfer student had the condition of spina bifida and the student was unable to empty the bladder voluntarily. The student was previously found eligible for special education services as "other health impaired." In order to participate in public school, the student's parents explained to the principal the student's need for clean intermittent catheterization (CIC) during the course of the school day. The school principal informed the parents when they registered the student and brought the student's IEP from the previous school, that the service of CIC could not be provided at the new school. The principal stated CIC was a medical service and the school could not be required to provide medical services.

The principal was incorrect and not in compliance with special education law.

The principal was correct and in compliance with special education law.

12. A first-grade music teacher taught a class "London Bridge," a game new to all the children. The game involved two students "trapping" a student between them and "locking them up" by jostling the trapped student. The music teacher set-up the students for the game, instructed them not to be silly, then turned and began writing on the blackboard. A student was trapped, jostled, and swung fast and hard. The trapped student was accidentally released, fell into the bookcase, and was injured, requiring $\mathbf{5 0}$ stitches to close the wound. Afterward, the student suffered recurring headaches.

The music teacher has no liability because "London Bridge" is an activity that many school children have participated in without injury and a teacher acting as a reasonably prudent person is not required to provide constant and direct supervision except during dangerous activities.

A reasonably prudent teacher could have foreseen possible injury and the teacher may face liability for negligent supervision in not providing close supervision in the early portions of the game.

13. A principal was hired on a probationary basis due to past performance. During the first year as principal, the superintendent often met with the principal to discuss performance in need of improvement including the principal's repeated tardiness to work. The superintendent subsequently documented in a letter the need to be at work by 8:00 a.m. Later, the superintendent made an early visit to school and the principal did not arrive until 8:10. After discussing the need to arrive by 8:00 a.m., the superintendent suggested that logging-in on the school computer serve as documentation of improvement for being on time. A second letter was sent documenting the behavior (lateness) and the suggestion for improvement. No document labeled "improvement plan" was developed.

The school board fulfilled its statutory obligations to the principal when it decided not to renew the contract because the principal had received all the protections of statute W.Va. Code § 18A-2-12.

The principal's contract must be renewed because no formal improvement plan had been implemented per W.Va. Code § 18A-2-12. 


\section{Williams School Law Survey, Nancy Ross Williams}

14. The high school music teacher needed sheet music, new risers, and a new sound system for school choir classes. The teacher had been repeatedly told that the school did not have the necessary funds to buy the items. Later that month, the newspaper reported an athletic team was to receive new uniforms because it was competing in the playoffs. In anger, the teacher wrote a letter to the editor of the town's weekly newspaper, critical of how funds were spent valuing sports over the arts. In the letter, the teacher did mention some halftruths, but did not direct them at any one individual by name. The statements in the letter were not aimed at any person with whom the teacher would come in contact in carrying out assigned duties, and the the half-truths were not carelessly made nor did they impede school operations. At the end of the month, the teacher was fired for insubordination. The school district

had the right to terminate the music teacher because the teacher publicly criticized the district and gave inaccurate information and was insubordinate.

had no basis to fire the music teacher because teachers have First Amendment rights.

15. A teacher was raped, had a child out of wedlock, and made the choice to be a single mother. The principal made a recommendation to the school board for the teacher's employment to be terminated on the basis of immorality. In defending herself from dismissal, she cited her right to privacy.

The school board is justified in firing the teacher because her behavior violated prevailing community norms.

The teacher's right to choose childbirth over abortion is encompassed in the constitutional right to privacy. 


\section{Williams School Law Survey, Nancy Ross Williams}

Survey Part 3 of 4

Read each statement and select true or false.

1. An accident, which could have been foreseen and prevented by "reasonable" care, may constitute negligence.

True

False

2. A principal must obtain a search warrant before searching a student's locker, pockets, or purse.

True

False

3. A school district may be held liable when reports of sexual harassment are made and the principal does not follow-through.
True
False

4. Teachers may be fired for their oral and written statements clearly critical of school authorities, even if the statements have no effect on school operations or objectives.
True
False

5. The Individuals with Disabilities Education Act 2004 specifically establishes standards prescribing the maximum level of education to be accorded children with disabilities.

True

False

6. The principal cannot compel a student to salute the flag or recite the Pledge of Allegiance.

True

False

7. A school administrator with a specific deficiency must always be given a formally labeled improvement plan prior to non-renewal.
True
False 


\section{Williams School Law Survey, Nancy Ross Williams}

8. A parent may challenge the accuracy of educational records that the school maintains about their children

True

False

9. Schools have the authority to report suspected child abuse without seeking the permission of the parents.
True
False

10. A principal may not have control over the content of a valedictorian speech at graduation and the student may include an unplanned prayer.
True
False

11. Because the Individuals with Disabilities Education Act of 2004 elaborates a clear preference for mainstreaming, every child with a disability must attend school in a regular classroom for at least part of the day.

True

False

12. Unwed pregnant teachers may be dismissed due to immorality.
True
False

13. School staff may be required to provide clean intermittent catheterization (CIC) services to a special education student during the school day in order for a student to benefit from special education services.
True
False

14. Equal access law that allows students to form religious clubs does not entitle the club to the same access to school facilities as for other non-curricular student clubs because of the separation between church and state.

True

False 


\section{Williams School Law Survey, Nancy Ross Williams}

15. Invocations and benedictions are not an acceptable part of public school graduations.

True

False 


\section{Williams School Law Survey, Nancy Ross Williams}

Survey Part 4 of 4

1. Explain what you liked/disliked about the teaching style(s) used in the school law course (s) you took in your university principal preparation program.

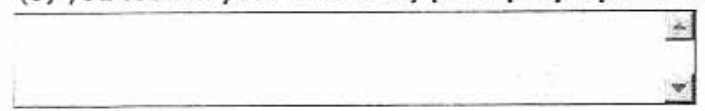

2. What area(s) of school law do you recommend for more university preparation in school law coursework?

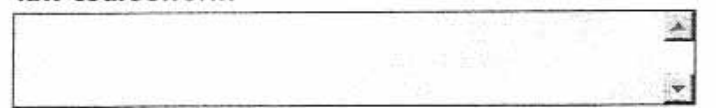

3. What areas of school law would you recommend for professional development in order to have a better background or better understanding?

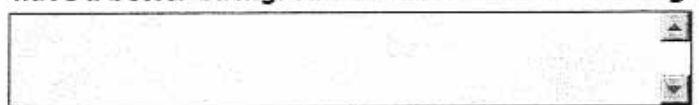

4. Check any areas of school law you feel would be most beneficial for principals' professional development

$\square$ student issues

facuity issues

$\square$ church-state issues

$\square$ tort liability

$\square$ special education

$\square$ other (fill-in below)

5. Other area of school law suggested for professional development 
Appendix E: Survey Sources and Legal References

THIS CHART AND SURVEY QUESTIONS ARE NOT DESIGNED TO PROVIDE AUTHORITATIVE INFORMATION ABOUT EDUCATION TOPICS AND ARE NOT PROVIDED AS LEGAL ADVICE. THE INFORMATION MAY NOT BE ACCURATE FOR USE IN ALL SITUATIONS. THE READER IS ENCOURAGED TO CONTACT LEGAL COUNSEL, IF LEGAL ADVICE IS NEEDED. ADDITIONALLY, THE INFORMATION PROVIDED MAY NOT BE ACCURATE FOR STATES OTHER THAN WEST VIRGINIA. AS THE AUTHOR, I BEAR SOLE RESPONSIBILITY FOR ANY ERRORS OF FACT OR INTERPRETATION.

\section{CHURCH AND STATE}

Case-Based Application Scenario

Survey Question Source: Schlosser, adapted

A student-formed Christian club followed school-use procedures to request use of the high school campus before and after school for religious discussion and worship. The school had several other non-curricular clubs, including a ski group, and a service organization, that used the school during non-instructional time. The district

False - may refuse to allow the club because it breaches the wall of separation between church and state.

True- must allow the Christian club access to the school during non-instructional time.

\section{Fact-based Knowledge}

True/False Question Source: Brabrand, adapted by Williams

Equal access law that allows students to form religious clubs does not entitle the club to the same access to school facilities as for other non-curricular student clubs because of the separation between church and state. FALSE

Legal Reference: Religious clubs - District \& School policy for use of school facilities during non-instructional time must provide equal access.

Case Law: Widmar v. Vincent, U.S., 1981; Equal Access Act, 1984

Board of Education of the Westside Community Schools v. Mergens, 496 U.S. 226 (1990)

Case-Based Application Scenario

Survey Question Source: Williams (Note: based on a WV case)

During the first day of school, a high school student refused to stand, say the Pledge of

Allegiance, or salute the American flag after morning announcements. The teacher confronted the student who continued to refuse to participate in the pledge activity. The teacher then sent the student to the principal's office.

False - The principal must explain to the student the school's expectation that all students participate in the pledge activity or face the threat of disciplinary action.

True - The principal cannot compel the student to participate or threaten disciplinary action.

\section{Fact-based Knowledge}

True/False Question Source: Brabrand, adapted by Williams

The principal cannot compel a student to salute the flag or recite the Pledge of Allegiance. TRUE 
Legal Reference: Flag salute - The state cannot compel a student to recite the Pledge of Allegiance.

Law: Free Speech Clause of the First Amendment of the U.S. Constitution;

Case Law: West Virginia State Board of Education v. Barnette, Supreme Court of U.S., 1943

\section{Case-Based Application Scenario}

Survey Question Source: Williams

In planning the graduation ceremony, a student advisory committee submitted plans to the principal in advance for approval. Several students planned to lead the audience in an opening choral response prayer to be printed in the graduation program. Because the plan for the prayer was student initiated, the principal of the school approved the student-advisory committee recommendation.

False - The principal acted correctly because this is a free speech issue.

True- The principal should not have approved student-led prayer because of the establishment clause.

\section{Fact-based Knowledge}

True/False Question Source: Brabrand

Invocations and benedictions are not an acceptable part of public school graduations. TRUE

Legal Reference: Prayer at school events - The principal cannot approve planned prayer during school events. Law: First Amendment of the U.S. Constitution, Establishment Clause. U.S. Supreme Court, Sante Fe Independent School District v. Doe, 530 U.S. 290 (2000) http://caselaw.lp.findlaw.com/scripts/getcase.pl?navby=case\&court=US\&vol=530\&page=290

\section{FACULTY ISSUES}

\section{Case-Based Application Scenario}

Survey Question Source: Williams (Note: This scenario was based on a WV case)

A principal was hired on a probationary basis due to past performance. During the first year as principal, the superintendent often met with the principal to discuss performance in need of improvement including the principal's repeated tardiness to work. The superintendent subsequently documented in a letter the need to be at work by 8:00 a.m. Later, the superintendent made an early visit to school and the principal did not arrive until 8:10. After discussing the need to arrive by 8:00 a.m., the superintendent suggested that logging-in on the school computer serve as documentation of improvement for being on time. A second letter was sent documenting the behavior (lateness) and the suggestion for improvement. No document labeled "improvement plan" was developed.

False - The principa1's contract must be renewed because no formal improvement plan had been implemented per W.Va. Code § 18A-2-12.

True - The school board fulfilled its statutory obligations to the principal when it decided not to renew the contract because the principal had received all the protections of statute W.Va. Code $\S 18 \mathrm{~A}-2-12$. 


\section{Fact-based Knowledge}

True/False Question Source: Brabrand, adapted by Williams for WV

A school administrator with a specific deficiency must always be given a formally labeled improvement plan prior to non-renewal. FALSE

Legal reference: Administrator appraisals and dismissals - A formal improvement plan was not required for the probationary principal's non-renewal given all evidence.

207 W. Va. 513, 534 S.E.2d 378 (2000)

Case Law: Supreme Court of Appeals of WV, January 2000 Term, No. 26567

MARTHA J. BAKER, Plaintiff, Appellee v. Board of Education, County of Hancock; Appeal from the Circuit Court of Hancock County; Honorable Ronald Wilson, Judge; Case Nos. 98P-29 and 97-P-39W; REVERSED

\section{Case-Based Application Scenario}

Survey Question Source: Littleton

The high school music teacher needed sheet music, new risers, and a new sound system for school choir classes. The teacher had been repeatedly told that the school did not have the necessary funds to buy the items. Later that month, the newspaper reported an athletic team was to receive new uniforms because it was competing in the playoffs. In anger, the teacher wrote a letter to the editor of the town's weekly newspaper, critical of how funds were spent valuing sports over the arts. In the letter, the teacher did mention some half-truths, but did not direct them at any one individual by name. The statements in the letter were not aimed at any person with whom the teacher would come in contact in carrying out assigned duties and the half-truths were not carelessly made nor did they impede school operations. At the end of the month, the teacher was fired for insubordination. The school district

False - had the right to terminate the music teacher because the teacher publicly criticized the district and gave inaccurate information and was insubordinate.

True - had no basis to fire the music teacher because teachers have First Amendment rights.

\section{Fact-based Knowledge}

True/False Question Source: Brabrand

Teachers may be fired for their oral and written statements clearly critical of school authorities, even if the statements have no effect on school operations or objectives. FALSE

Legal Reference: Teacher freedom of expression - Teacher was within freedom of expression rights. The letter did not have an effect on school operations or objectives. Case Law: Pickering v. Board of Education, Supreme Court of U.S., 1968. 


\section{Case-Based Application Scenario Survey Question Source: Williams}

A teacher was raped, had a child out of wedlock, and made the choice to be a single mother. The principal made a recommendation to the school board for the teacher's employment to be terminated on the basis of immorality. In defending herself from dismissal, she cited her right to privacy.

False - The school board is justified in firing the teacher because her behavior violated prevailing community norms.

True - The teacher's right to choose childbirth over abortion is encompassed in the constitutional right to privacy.

\section{Fact-based Knowledge}

True/False Question Source: Brabrand, adapted by Williams

Unwed pregnant teachers may be dismissed due to immorality. FALSE

Legal reference: Teacher right to privacy - The right to choose childbirth over abortion is encompassed in the constitutional right to privacy established by Roe v. Wade and the due process clause of the 14th Amendment.

Case Law: Eckmann V. Board of Education, U.S. District Court, 1986.

\section{SPECIAL EDUCATION}

\section{Case-Based Application Scenario}

Survey Question Source: Williams

A second-grade child, who is profoundly deaf, attends a public school. The student's present level of educational performance is on grade level with grades of A and B in all subjects. At the Individualized Education Program (IEP) meeting, the child's parents, who are also deaf, request a full-time certified sign-language interpreter be included believing total communication is needed because their child is deaf. The principal and other members of the IEP team, except the parents, refuse to provide a sign-language interpreter, based on the student's performance at the current level of services.

False - The IEP team must consider and agree with the parents' request in order to comply with special education law.

True - The IEP team must consider and may refuse the parents' request and still be in compliance with special education law.

\section{Fact-based Knowledge}

True/False Question Source: Williams

The Individuals with Disabilities Education Act 2004 specifically establishes standards prescribing the maximum level of education to be accorded children with disabilities.FALSE

Legal Reference: Free Appropriate Public Education (FAPE) A sign language interpreter was not required for the student to have access and make progress in the general curriculum as evidenced by the student's academic success at the present level of service without a sign language interpreter. Law: The Education for All Handicapped Children Act of 1975;

Case Law: Board of Education of Hendrick Hudson Central School District v. Rowley, 1982. 


\section{Case-Based Application Scenario \\ Survey Question Source: Power, adapted by Williams}

An IEP meeting was held with parents of a child with severe mental impairment and multiple disabilities. Services in place at the time of the meeting included a self-contained classroom in which all students were students with severe mental impairment and multiple disabilities. During the annual IEP meeting, the parents insisted that their child receive all special education services in regular education classes, which they considered the least restrictive environment. The principal responded by informing the parents that the school could not consider such a placement due to the severity of the impairments and maintained that the student's current placement was the most appropriate educational placement.

False -The IEP team must agree with the parents' request to include the student in regular education classes for all or part of the day in order to meet requirements for least restrictive environment.

True - The IEP team must consider the parents' request for change of placement based on the least restrictive environment along with other considerations, and then may refuse the parents' request.

\section{Fact-based Knowledge}

True/False Question Source: Williams

Because the Individuals with Disabilities Education Act of 2004 elaborates a clear preference for mainstreaming, every child with a disability must attend school in a regular classroom for at least part of the day. FALSE

Legal Reference: Least Restrictive Environment (LRE) Inclusion in a regular education classroom is not required for every student. The IEP team must consider parent input but may refuse a parent request.

IDEIA 2004

Case-Based Application Scenario

Survey Question Source: Williams

A transfer student had the condition of spina bifida and the student was unable to empty the bladder voluntarily. The student was previously found eligible for special education services as "other health impaired." In order to participate in public school, the student's parents explained to the principal the student's need for clean intermittent catheterization (CIC) during the course of the school day. The school principal informed the parents when they registered the student and brought the student's IEP from the previous school, that the service of CIC could not be provided at the new school. The principal stated CIC was a medical service and the school could not be required to provide medical services.

False - The principal was incorrect and not in compliance with special education law. True - The principal was correct and in compliance with special education law.

\section{Fact-based Knowledge}

True/False Question Source: Williams

School staff may be required to provide clean intermittent catheterization (CIC) services to a special education student during the school day in order for a student to benefit from special education services. TRUE 
Legal Reference: Related Services: Since petitioner School District received federal funding under the Education of the Handicapped Act it was required to provide the child with "a free appropriate public education," which is defined in the Act to include "related services," which are defined in turn to include "supportive services (including . . . medical . . . services, except that such medical services shall be for diagnostic and evaluation purposes only) as may be required to assist a handicapped child to benefit from special education." Law: Education of All Handicapped Children Act of 1975; Case Law: Irving Independent School District v. Tatro, Supreme Court of the U.S., 1984.

\section{STUDENT ISSUES}

Case-Based Application Scenario

Survey Question Source: Littleton

A Journalism class submitted its school newspaper for review by the principal before publishing. In the newspaper, two sections contained content that was sure to raise eyebrows. The first section included a story of three students (whose names had been changed) and their experiences with pregnancy. The second section was a story about how divorce had affected one of the students on campus. The stories presented only the students' points of view. The parents of the students in the stories were not allowed to defend any statements about them or their situation. Legally, the principal

False - cannot require the students to omit the sections because of the students' first amendment rights.

True - can remove the sections without infringing on the students' first amendment rights.

\section{Fact-based Knowledge}

True/False Question Source: Brabrand, adapted by Williams

A principal may not have control over the content of a valedictorian speech at graduation and the student may include an unplanned prayer. TRUE

Legal Reference: Student freedom of expression - Principal was correct in exercising editorial control over contents of the high school newspaper.

Case Law: Hazelwood School District v. Kuhlmeier, Supreme Court of the U.S., 1988

\section{Case-Based Application Scenario}

Survey Question Source: Williams

An honor roll student expected to be inducted into the school's honor society. However, the student was not among the students named in announcement to participate in the induction meeting. The student's parents contacted the principal and stated that because of their FERPA rights, they had the right to review teacher ratings of their student as well as those of students admitted to the honors society. The parents threatened to get a lawyer and sue unless their request was met.

False - The principal must comply with the parent request.

True - The principal must deny the parent request. 


\section{Fact-based Knowledge}

True/False Question Source: Brabrand, adapted

A parent may challenge the accuracy of educational records that the school maintains about their children. TRUE

Legal Referece: Student records - Faculty ratings for admission to a school club are not school records; parents have a right to appeal anything in a student's file that is considered incorrect.

Law: Family Educational Rights and Privacy Act of 1974 (FERPA)

WV Policy 4350, "Collection, Maintenance and Disclosure of Student Data”

http://wvde.state.wv.us/policies/p4350.html

\section{Case-Based Application Scenario}

Survey Question Source: Schlosser, adapted by Williams

A student was left alone in the assistant principal's office for a few moments and when the assistant principal returned, they had a brief conversation. The student then picked up his backpack and left to go to his locker and on to class. A short time after, the assistant principal discovered a bank envelope with ticket money was missing. The student had a record of thefts and was the only person in the office prior to the theft. Board policy does permit general searches and students are notified of this fact through the student code of conduct. The assistant principal

False- does not have cause to search the student's locker without a search warrant.

True - has cause to search the student's locker without a search warrant.

\section{Fact-based Knowledge}

True/False Question Source: Brabrand

A principal must obtain a search warrant before searching a student's locker, pockets, or purse. FALSE

Legal Reference: Search and seizure - Based on reasonable suspicion, the principal may legally search the student's locker.

Case Law: New Jersey v. T.L.O., Supreme Court of the U.S., 1985

WV Supreme Court of Appeals locker search case, State v. Joseph T., 175 W. Va. 598, 336

S.E.2d 728 (1985) 


\section{TORT LIABILITY}

Case-Based Application Scenario

Survey Question Source: Williams

A first-grade music teacher taught a class "London Bridge," a game new to all the children. The game involved two students "trapping” a student between them and "locking them up" by jostling the trapped student. The music teacher set-up the students for the game, instructed them not to be silly, then turned and began writing on the blackboard. A student was trapped, jostled, and swung fast and hard. The trapped student was accidentally released, fell into the bookcase, and was injured, requiring 50 stitches to close the wound. Afterward, the student suffered recurring headaches.

False - The music teacher has no liability because "London Bridge" is an activity that many school children have participated in without injury and a teacher acting as a reasonably prudent person is not required to provide constant and direct supervision except during dangerous activities.

True - A reasonably prudent teacher could have foreseen possible injury and the teacher may face liability for negligent supervision in not providing close supervision in the early portions of the game.

\section{Fact-based Knowledge}

True/False Question Source: Brabrand

An accident, which could have been foreseen and prevented by "reasonable” care may constitute negligence. TRUE

Legal Reference: Liability of school personnel: standard of care. Mere instruction to first grade children in how to play a game without direct supervision was negligent supervision. Case Law: Johnson v. School District of Millard, Supreme Court of Nebraska, 1998. 


\section{Case-Based Application Scenario}

Survey Question Source: Littleton, adapted by Williams

A third grade student reported to school on more than one occasion with suspicious bruises on the student's body and face. The student's teacher questioned the student about the bruises. After the latest incident, the teacher decided there was reasonable cause to suspect the child was being abused and decided something must be done. The teacher is legally obligated to False - report the circumstances directly to the Department of Health and Human Resources within 48 hours without ever notifying a school administrator.

True - report the circumstances to the school administrator. The teacher or administrator must then make a report to the Department of Health and Human Resources not more than 48 hours after the teacher reasonably suspected abuse.

\section{Fact-based Knowledge}

True/False Question Source: Brabrand, adapted by Williams

Schools have the authority to report suspected child abuse without seeking the permission of the parents. TRUE

Legal Reference: Liability of school personnel: duties of supervision Law: WV Code 49-6A-2.

\section{Case-Based Application Scenario}

Survey Question Source: Source: Littleton, adapted by Williams

A first-time principal was hired at a high school in August 2003. By the fall of 2005, complaints about one of the teachers had reached the principal. The complaints indicated that the science teacher had "befriended" one of his students, showed favoritism toward this young woman, and had begun a sexual relationship with her. In 2006, a student told the principal that she had witnessed the science teacher "molesting" one of the students in a private room of the school. The principal downplayed the incidents and did not attempt to warn or discipline the teacher. During the same year, a new superintendent was hired. The principal did not inform the superintendent of the situation.

False - The school district cannot be held liable because the principal had no proof of the accusation and did not inform the superintendent.

True - The school district may face liability for the principal's deliberate indifference to the situation.

\section{Fact-based Knowledge}

True/False Source: Brabrand, adapted by Williams

A school district may be held liable when reports of sexual harassment are made and the principal does not follow- through. TRUE

Legal Reference: Liability of school personnel: The principal exhibited deliberate indifference. Case Law: Gebser v. Lago Vista I.S.D. (U.S. 1988);

Doe v. Taylor I.S.D. (5th Cir. 1994) 
Survey Item resources:

Brabrand, S. S. (2003). Virginia Principals and School Law (Doctoral dissertation, Virginia Polytechnic Institute and State University). Retrieved from http://scholar.lib.vt.edu/theses/available/etd-05052003155102/unrestricted/ssb1final.pdf

Littleton, M., Higham, R., \& Styron, K. (2001 ). Analysis of legal knowledge of school officials in Texas. Paper presented at the Education Law Association.

Power, D. (2007). A study of selected Virginia principals' knowledge of special education law (Doctoral dissertation). Virginia Polytechnic Institute and State University Blacksburg, VA etd-01252007-110510

Schlosser, R. (2006). An analysis of principal interns' legal knowledge and legal instruction in principal preparation programs (Unpublished doctoral dissertation). Sam Houston State University, Huntsville, TX

THIS CHART AND SURVEY QUESTIONS ARE NOT DESIGNED TO PROVIDE AUTHORITATIVE INFORMATION ABOUT EDUCATION TOPICS AND ARE NOT PROVIDED AS LEGAL ADVICE. THE INFORMATION MAY NOT BE ACCURATE FOR USE IN ALL SITUATIONS. THE READER IS ENCOURAGED TO CONTACT LEGAL COUNSEL, IF LEGAL ADVICE IS NEEDED. ADDITIONALLY, THE INFORMATION PROVIDED MAY NOT BE ACCURATE FOR STATES OTHER THAN WEST VIRGINIA. AS THE AUTHOR, I BEAR SOLE RESPONSIBILITY FOR ANY ERRORS OF FACT OR INTERPRETATION. 


\section{Appendix F: Permission to Use Survey Items - Dr. Brabrand}

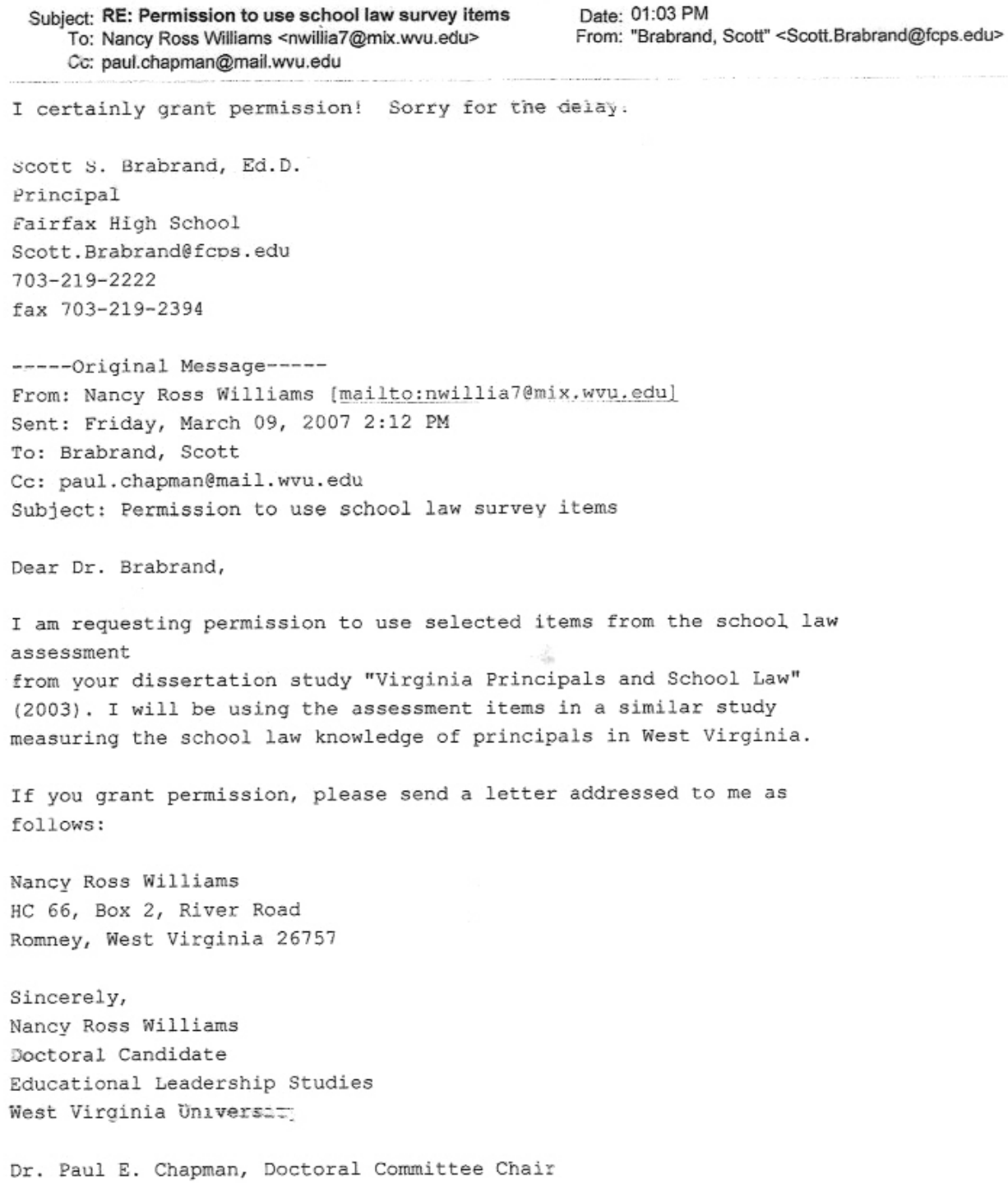




\section{Appendix G: Permission to Use Survey Items - Dr. Littleton}

Subject: R: permission to use law survey items To: Nancy Ross Williams <nwillia7@mix.wvu.edu>
Date: 01:51 PM

From: "Littleton, Dr. Mark" <MLITTLETON@tarleton.edu>

You may have my permission. You might want to check out the adapted version used by Rebecca Schlosser in her dissertation at Sam Houston State University in 2006. Good luck.

Mark Littleton, Ed.D.

Professor of Educational Leadership

Tarleton State University

Da: Nancy Ross Williams [mailto:nwillia7@mix.wvu.edu]

Inviato: ven 09/03/2007 13.05

A: Littleton, Dr. Mark

Cc: paul.chapman@mail.wvu.edu

Oggetto: permission to use law survey items

Dear Dr. Littleton,

I am requesting permission to use items from the school law assessment from Littleton et al. (2001). I will be using the assessment in a

similar study measuring the school law knowledge of principals in West

Virginia.

If you grant permission, please send a letter on Tarleton State

University letterhead addressed to me as follows:

Nancy Ross Williams

HC 66, Box 2, River Road

Romney, West Virginia 26757

Sincerely,

Nancy Ross Williams

Doctoral Candidate

Educational Leadership Studies

West Virginia University

Dr. Paul E. Chapman, Doctoral Committee Chair 


\section{Appendix H: Permission to Use Survey Items - Dr. Power}

\section{RE: dissertation copy request}

From: Dr. Donna Power (dpower@mathews.k12.va.us)

Sent: Tue 5/01/07 1:42 PM

To: Nancy Williams (nancy_williams1@hotmail.com)

Dear Nancy,

I'd like to helo but I am getting ready to publish my paper and need to keep it out of circulation for the nest several months.

You certainly can use items from the survey.

Donna

-..--original Message-...-

From: Nancy Williams [mailto:nancy williamslehotmail.com

Sent: Tuesday, May 01, 2007 9:31 AM

To: Dr. Donna Power

Subject: RE: dissertation copy request

Dear Dr. Power

Thank you very much for sending the survey instrument. I would like to four of your questions into my survey. I will need to

cite your dissertation and include information about the reliability and validity of your questions as I have for the other survey questions I used

from Littleton and Brabrand. Also, I would need your permission to use

the

items!

May I access your entire work and include it in my literature review?

May I

have your permission to use selected survey items from your research?

isncerely,

Nancy Ross Williams

$>$ From: "Dr. Donna Power" <doower@mathews.k12.va.us>

$>$ To: "Nancy Williams" <nancy williamslenotmail. com

$>$ Subject: RE: dissertation copy request

Date: Sat, 28 Apr 2007 19:37:58 -0400

sorry for the delay.

Good lack

$>$ Donna

$>$ 
Appendix I: Permission to Use Survey Items - Dr. Schlosser

Subject: RE: school law survey items

To: 'Nancy Williams' <nwillia7@mix.wvu.edu>
Date: 11:01 AM

From: Rebecca Schlosser <rschlosser@sulross.edu>

Yes, you are welcome to use the survey items. I am thrilled that you are working on the topic. If you need something faxed or mailed, just let me know.

\author{
$\mathscr{R}_{\text {ebecca }}$ Śtilosser \\ Rebecca Schlosser, J.D., Ed.D. \\ Assistant Professor \\ Educational Administration Program \\ Sul Ross State University \\ Alpine, Texas \\ rschlosser@sulross.edu \\ (432) $837-8173$
}


Appendix J: Curriculum Vitae

Nancy Ross Williams

\section{DEGREES:}

B.A. University of North Carolina Major: Radio, TV, Motion Pictures 1976 Chapel Hill, North Carolina

M.A. North Carolina Central University Durham, North Carolina

Major: Instructional Media Minor: Educational Psychology

M.A. Hampton University Major: Spec. Ed., Hearing Impairment 1987 Hampton, Virginia

M.Ed. Vanderbilt University Nashville, Tennessee Major: Spec. Ed., Visual Impairment 1996

Licensure Certificate Program, Salem International University $\quad$ Educational Leadership Certificate 2003 Salem, West Virginia

Ed.D. West Virginia University Major: Educational Leadership Studies Morgantown, West Virginia Research Emphasis: School Law Minor: Special Education Administration

California State University Coursework started leading to Assistive Technology Dominguez Hills, California

Specialist certificate Fall 2009-present

\section{LICENSURE:}

State of West Virginia - Permanent

Professional Teaching Certificate, Early Education

Professional Teaching Certificate, Elementary Education

Professional Teaching Certificate, Hearing Impaired K-12

Professional Teaching Certificate, Visually Impaired K-12

Professional Administrative Certificate, Superintendent PK-Adult

Professional Administrative Certificate, Supervisor General Instruction PK-Adult

Professional Administrative Certificate, Principal PK-Adult

Commonwealth of Virginia - July 1, 2008 to June 30, 2013

Administration and Supervision PreK-12

Elementary Education PreK-6

Hearing Impairment PreK-12

Visual Impairment PreK-12 


\section{EMPLOYMENT:}

WDUR Radio, Durham, NC

1977-1978

WDBS-FM, Duke University, Durham, NC

1978-1980

WKIX/WYYD News, Raleigh, NC

1980-1981

Manager Special Communication Services, CenTeX, Williamsburg, VA 1981-1983

Radio reading service for the blind and radio TTY service for the deaf

Full-time Substitute Teacher, classroom and speech

1983-1987

West Virginia Schools for the Deaf and the Blind (WVSDB) Romney, WV

Contract Early Interventionist, WVSDB SKI*HI Program

1985-1987

Early Intervention Parent Advisor WVSDB SKI*HI Program

1987-1988

Statewide Director and Trainer, Early Intervention WVSDB SKI*HI

1988-1991

Teacher WV School for the Blind, VI \& Multiple Disabilities 1991-1993

Contract Early Interventionist, WVSDB SKI*HI, InSite, VIISA 1993-1996

Early Childhood Teacher, WVSD Elementary 1996-1997

VI/HI Itinerant teacher, WVSDB Outreach, and IEP Coordinator

Director of Student Life, WVSD Secondary

June 2006- Jan 2008

Coordinator Special Instructional Services

Frederick County Public Schools, Winchester, VA Jan 2008- present

\section{HIGHER EDUCATION EXPERIENCE:}

Eastern WV Community and Technical College

2003-2006

Moorefield, West Virginia

Curriculum consultant for the WVSDB Residential Care Certificate Program

Adjunct faculty lecturer, PSY 219: the Exceptional Child

Fall 2003/2004

Instructor, Apprenticeship in Child Development Specialist (ACDS) Spring 2005 Moorefield, West Virginia

Potomac State College of West Virginia University $\quad$ Fall 2005, Spring 2006

Keyser, West Virginia

Adjunct Instructor Communication 100 \& 104

West Virginia University, Dept. of Special Education, Adjunct Instructor 2008 - present 


\section{PROFESSIONAL PAPERS AND PRESENTATIONS:}

Chapman, P.E., Cunningham, M., Heinen, E.B., Heinlein, C.K., E.B., McCue, L., Nicholson, B. \& Williams, N.R. (August 2007) The West Virginia Institute for $21^{\text {st }}$ Century Leadership: How West Virginia is Modeling the Way for Building the Teaching, Learning, and Leadership Centers of Tomorrow. National Council of Professors of Educational Administration (NCPEA). Chicago, IL

Williams, N.R. (October 2007). Instructional Strategies for Educating Students with Visual Impairments with other Disabilities. WVSDB Harvest of Connections Statewide Conference. Romney, WV

Williams, N.R. (August 2006) Application of the NAEYC Code of Ethical Conduct in Residential Child Care for Students with Disabilities. WVSDB Staff Development. Romney, WV

Williams, N.R. (August 2004) Using “I-Know” to Develop IEP Goals. WVDE Technology Conference. Charleston, WV

Adrian, H. \& Williams, N. R. (October 2004) “I-Know” Applications for IEP Development. WV Council for Exceptional Children Conference. Snowshoe, WV

Willams, N.R. (1997-2004) In-service presentations for inclusion teachers of students who are hard of hearing, and blind and partially sighted, in Pendleton, Grant, Morgan, Mineral, and Hampshire Counties

Williams, N.R. (Spring 2003) Short-term Intervention and Outreach Services offered by WVSDB. RESA II, Huntington, WV; RESA VI, Wheeling, WV; and RESA VIII, Martinsburg, WV

Williams, N.R. (October 1998) Mediated Learning Strategies and Instrumental Enrichment, WVSDB Fall Conference, Romney, WV 